Sign Systems Studies 33.1, 2005

\title{
The semiotics of sexuality: The choice becomes the association of habits becomes the desire becomes the need
}

\author{
Stephen Jarosek \\ PO Box 124, Armadale WA 6992, Australia \\ e-mail: stejaros@iinet.net.au
}

\begin{abstract}
Pragmatism is the idea that we attribute meaning to things that matter to us. Ultimately, the things that matter are intercepted by our bodies - our eyes, ears, nose, hands, feet, skin — right down to our sex differences. Our bodies are the tools with which we interface with the world - the cultural world. Sex differences provide major insights into how the body impacts on experience and thus, personality and ultimately culture's gender roles. In my earlier paper, I discuss what Peirce identified as fundamental aspects of cognition - habits and associative learning - and I place them in the context of Heidegger's Dasein. In this current paper, I develop on these ideas in order to apply them to understand gender roles. From the inextricable connection between habits, associative learning and Dasein, we can infer the following: (1) Gender roles are habits; (2) Gender roles are chosen; (3) Men and women "like" the roles to which they have been assigned (this is a fundamental expression of Dasein). That is to say - the choice becomes the association of habits becomes the desire becomes the need. Hence arise the needs by which gender roles are identified.
\end{abstract}

\subsection{Introduction}

Ludwig Wittgenstein had famously observed that even if a lion could speak, we would never be able to understand it. A semiotician would justifiably ponder whether such a creature could still be considered to be a lion.

At one time or another, most of us have probably toyed with the notion of meeting an alien who could speak our language. What insights would such a being impart? Would we be able to understand 
him or her? Such naïve fantasies generally fail to demonstrate any awareness of the simple truth that even two humans from different cultures often fail to understand one another - and so how could any human possibly hope to understand an alien?

The unspoken assumption of any naïve dreamer is, of course, that an alien is "like me", in that there is an "objective" world "out there" that has only one "correct" way of being interpreted, a way that one would expect to be shared by all other "intelligent" organisms. The SETI program itself is predicated on this unspoken assumption, with little thought being given to the possible reasons why advanced civilizations may not want to communicate with us. This problem has its origins in the reductionism (determinism ${ }^{1}$ ) that has dominated most of modern science. Accordingly, a deterministic perspective invariably assumes that an autistic or schizophrenic or homosexual person, for example, has a "problem" in need of treatment (instead of choices to be reconciled), because they do not share our "correct" interpretation of the world.

In this light, can we expect a mere mortal to gain any insights from a brief encounter with an alien? Probably not. Indeed, humans often fail to understand each other, even when they come from within the same culture, share the same work environment and are of the same gender. They don't get to realize that all they ever have are assumptions, not truths.

The vast majority of us aren't even aware that in the course of our daily lives, we are interacting with aliens more incomprehensible to us than any conceptualization that we might entertain as to what an alien is supposed to be. We don't realize that our opposite sex inhabits a world that is entirely different to our own.

I prefer to use the word "determinism" (in the sense of "genetic determinism") in preference to "reductionism" to describe narrow, "linear" thinking. Ultimately, good, competent synthesis is a form of reduction to fundamental principles (as per "the law of association of habits"), which is quite different to "linear" and "deterministic" thinking. 


\subsection{Back to basics}

In my paper (2001) titled "The law of association of habits", I explore Peirce's "Law of association of ideas", in order to derive some general principles of cognition. Now, in this paper, I apply these general principles in order to explore the nature of human sexuality.

\subsection{The desire to be}

In my previous paper (2001) I introduce the notion of "the desire to be". The closest analogue to this concept is Heidegger's (1978) Dasein. Both the desire to be (in the context that I use it) and Dasein are concerned with being and they are essentially the same thing ${ }^{2}$. However the interpretation introduced in my previous paper (2001), is a slightly different slant on the most commonly accepted interpretation of Dasein particularly as it relates to desire. In this context, the desire to be is the central aspect of Dasein. An organism's every desire is a manifestation of its desire to be. Being is the desire to be. Suspended within its ecology, an organism makes choices and those choices have to be consistent with what that organism is. Choice implies motivation. An organism "likes" being what it is, and its Dasein motivates it to make those choices that are consistent with its condition.

Dasein is the assumption I apply to infer and predict a great many things about behavior. Essentially, Dasein tells us that the circumstances within which an organism finds itself become part of that organism's context (world view — "Umwelt") that it "desires". When it adapts in order to accommodate the circumstances within which it finds itself, it makes choices from its ecology. Its complicity is a statement that it "likes" its interpretation of the world.

As far as humans are concerned, we can now infer, from our understanding of Dasein, that men and women "like" the roles to which they have been assigned. And we need no further proof than their complicity.

2 Heidegger also refers to the desire to be, but in an entirely different context, as but one aspect of Dasein. 


\subsection{The law of association of habits}

We also know, from Peirce's (1966) Great Law of Association of Ideas, that gender roles are habitual and associative:

There is a law in this succession of ideas. We may roughly say it is the law of habit. It is the great "Law of the Association of Ideas", - the one law of all psychical action. (CP 7.388)

By incorporating the semiotic view of habit, association and logic, we can better begin to understand how the gender that habituates the sustaining of the known (e.g., nurturing) is going to have different predispositions and responsibilities to the gender that habituates exploring the unknown (e.g., finding solutions to problems).

In Dasein and the law of association of habits, we have a basic framework from which to infer and predict the logics by which humans interpret their worlds as men and women (and from which we might extrapolate to infer some things about the logics of non-human organisms).

\subsection{The basic model}

Let us integrate the above points, within the context of the law of association of habits, to arrive at a synthesis for modeling human sexuality:

(1) Gender roles are habits, ipso facto;

(2) Gender roles are chosen, ipso facto;

(3) Men and women "like" the gender roles to which they have been assigned.

Also from my paper (2001), we will recall the important relationship that exists between the tools at our disposal (our bodies) and the choices we make. We recall Mark Twain's famous aphorism:

A man whose only tool is a hammer will perceive the world in terms of nails.

Because this paper is about human sexuality, we will need to interpret the significance of this aphorism with respect to gender roles: 
A human whose only tool is a man's body will perceive the world in terms that are different to a human whose only tool is a woman's body.

This presents us with a theory that unifies the associative/habitual aspects of cognition with physiology - the inextricable connection between mind and body. This fundamental set of principles will enable us to understand how the psychological differences between men and women emerge within Culture. Within the context of the mind-body unity, our fundamental model can be summarized succinctly:

The choice becomes the association of habits becomes the desire becomes the need.

And within the context of autopoiesis theory, self-referencing is related to the bi-directional nature of cognitive processes. That is, there is not just one direction of cause and effect. The above principle can be expressed in reverse order:

The need is the desire is the habituation of associations that predisposes us to the types of choices we make.

\subsection{It's all about choice}

Our basic model provides us with the foundations for understanding the importance of choice. Human and non-human organisms change with the choices they make. Our brains self-organize in order to accommodate and make sense of our experiences.

\subsection{Choices for courses}

Children raised by wolves. John McCrone (1993) observes that the behavior of feral children has much in common with the behavior of the wild animals that raised them - for example, their lack of memory and self awareness. Even the voices of people are, like background noises such as the rumbling of distant traffic, without meaning to them. The genetic-deterministic position is likely to account for their extraordinary behavior in terms of brain damage, perhaps from the stress of survival. But what if this assumption is 
wrong? Feral children make choices from the options presented to them by their animal environments. Are feral children, in a very real sense, animals? Do their brains (and bodies) self-organize - in response to the choices they make - in order to accommodate a way of perceiving their worlds that is real and legitimate, as wild animals do all the time?

Domestic animals. We know that a twist to the phenomenon of feral children is perfectly common. We domesticate animals all the time. They lose their feral natures to become "civilized", insofar as their bodies allow them to. A domesticated cat behaves very differently to a feral one. The genetic-deterministic position is likely to account for the domestication of animals in terms of the expression of genes. The semiotic position accounts for domestication in the context of the choices that the pet is presented with, within its domestic environment.

Career choice. Choice of career is more than a lifestyle choice. It is a personality choice. Artists are different to accountants, who are different to physicists who are different to musicians and architects, plumbers and chefs. The choices we make shape what we become.

Gender roles. Gender roles are choices. A human whose only tool is a man's body will perceive the world in the competitive terms that only a man can understand. A human whose only tool is a woman's body will perceive the world in the gatekeeper terms that only a woman can understand.

\subsection{Gender roles, initial conditions and matriarchal power}

An important aspect of matriarchal power is based on the female role across almost all cultures as primary nurturer. The importance of the role of the primary nurturer can be appreciated from the perspective of "initial conditions" - the hothouse in which an infant's initial choices are first made.

In my paper (2001) I explore the metaphor that compares a brain of neurons to a city of people. The infant's brain, like a city, selforganizes into its functional specializations, as it makes choices from the options that are presented to it. 
The "initial conditions" of a living system play a crucial role in the developmental trajectory that emerges over time. An infant's brain is a living system that is similarly subject to "initial conditions". Maternal influence and guidance provides an important "initial condition" impacting on the development of personality.

The first choices that an infant makes are influenced first and foremost by the primary nurturer. More often than not, that primary nurturer will be the female of the species. In most cultures, Mother is the primary nurturer. Mother provides the greatest influence upon the initial conditions to which a child is subjected - the initial conditions that have the greatest influence on how a young, malleable brain develops in the formative years.

And children grow up to become men and women.

In some rare instances, however, the "initial conditions" to which an infant is subjected might be provided by a wild animal - perhaps a wolf. Infants forced to make choices from this kind of maternal "initial condition" develop personalities that are distinctly feral. They never quite outgrow their beastly origins.

\subsection{Gender roles}

\subsection{Initial conditions}

Cultural logics are inextricably bound up with the bodies of men and women. Our physiologies are different in such a way that they provide complementarity in the logics that comprise culture. That is, culture culminates in a mutually agreeable division of labor between men and women, and the initial conditions for that division are provided by physiological sex differences. Woman is sexy and desirable. Man is sexy and desires. Desire and desirable are logically complementary. So far, so good.

But sexy in men is not the same as sexy in women. In fact, sexy in men describes something altogether different - something related to experience, courage, wisdom, savoir-faire. Sexy in women, on the other hand, alludes to vulnerability (the vulnerability of the known), nurturing, innocence and their relationship to the forbidden.

Of course it should be noted that the emphasis here is on western cultures, and for the purpose of simplifying our analysis, precludes 
those possibilities that might bear no resemblance to what we have come to know. It is beyond the scope of this paper to discuss the success or otherwise of the past half-century of liberalism and feminism to change this model ${ }^{3}$.

To clear up this anomaly with the definition of "sexy", simple observation will enable us to determine basic facts that we should regard as a given. Here is a pair of phenomena that are so pervasive and self-evident in our modern, western cultures that they need no further introduction:

(1) Irrespective of how uninspiring a woman might be from the perspective of her character or "intelligence", if she looks sexy, she will always be receiving overtures from men;

(2) Irrespective of how handsome, sexy or successful a man might be, irrespective of the extent to which women might strive to encourage him, to set the scene, to make themselves available, or to make things easy for him, if he does not initiate, he does not win any hearts.

\subsection{Predictable roles}

There's the old joke that in order to impress a woman, a man has to woo her, empathize with her, buy her flowers, make her laugh, entertain her, be her lover, be her friend, and the list goes on. Whereas all a woman has to do to impress a man is turn up naked with a beer. Joke as we might, there is a fundamental truth in this, at least in English-speaking cultures.

We should stress that this more sexist approach is a distinctly western phenomenon that is especially characteristic of the Englishspeaking world, where a more extreme form of sexism invariably accompanies a more extreme form of materialism (as a product of the Industrial Revolution). It is observed that in European and Asian cultures, for example, considerably more is expected of women by men, and it is common for women to express a subtler form of

\footnotetext{
3 In passing, however, some of us may have observed that old adage — "the more things change, the more they stay the same". Have we not noticed how what started out as a genuine movement to establish independence and basic rights for women has begun to transform itself into a modern form of chivalry/sexism that rivals what went before?
} 
"initiating" (in response to which the man "counter-initiates" — the woman's cue is interpreted as an invitation to initiate).

The two very different gender dynamics provide a kind of cultural "initial condition" that, as in chaos theory, set the foundations for divergent gender roles (memetic/semiotic attractors).

The cultural "initial condition" is related to the mind-body "initial condition" where, for example, the relatively spontaneous erections in men predispose them to initiating, in contrast to the evolving contexts that shape women's desires.

These very different gender perspectives provide the basis for interactions between men and women that are the expression of a very simple law of evolution. Darwin held that any ecology has to consist of producers of variety and filters of variety. Thus, the human ecology (culture) has men as its producers of variety and women as its filters of variety. What is more, these different roles are not merely "activities" that one can choose arbitrarily at will, but rather, they are manifestations of personality, habit and choice, and are inextricably interconnected with how reality is perceived.

As can be seen in these two dynamics (i.e., producing and filtering variety), women's power is the power of veto. Women are the gatekeepers of cultural norms, and they wield enormous influence in determining which elements of the unknown make it into the cultural known. As the filters of variety, women are predisposed to rejecting those aspects of appearance, behavior, belief, attitude, etc. that depart too far from what they regard as acceptably normal. As the producers of variety, however, men provide the stereotypes that are passed or vetoed by the female gatekeepers. Femininity seeks continuity and conformity, and nurturing, diplomacy and manipulation are consistent with such a priority. Masculinity seeks variety and novelty, and discovery, innovation and competition are the priorities of men.

We now have a basis on which to infer how the responsibilities of men and women emerge:

(1) The gender that has permission from Culture to be provided for, is the gender that prioritizes the known. The cultural known is Woman's primal "responsibility", and she senses what her obligations are with respect to networking, nurturing, culture and tradition. The choices that Woman makes, with her power of veto, provide a window to her soul. It is a sign of what she is; 
(2) The gender that provides is the gender that must compete for survival. The cultural unknown is Man's primal "responsibility", and he senses what his obligations are with respect to surviving, protecting, competition and pushing the boundaries. The choices that Man makes, when he must compete at the interface between being and not being, determine what he becomes.

\subsection{Sex roles and Culture}

The sex act itself has very different consequences for men and women, especially with regard to procreation, and so in itself provides the logical basis for the differing responsibilities of men and women.

To summarize from the perspective of chaos theory, sex roles as defined by the body can be interpreted as providing the initial conditions for the gender roles that precipitate throughout a culture. And gender roles provide the mechanism by which cultural habits are modulated - with masculinity being the agent of change, and femininity providing the resistance to change. That is, the priority of Woman is the cultural known, while that of Man is the interface between the cultural known and the unknown.

\subsection{The cultural known versus the unknown}

\subsection{Culture as a collective learning machine}

Howard Bloom (2000) identified five essential elements of a "collective learning machine" (in the case that we are interested in, human culture):

(1) conformity enforcers;

(2) diversity generators;

(3) inner judges;

(4) resource shifters;

(5) intergroup tournaments.

The first three elements are of particular interest in our analysis. The remaining two (resource shifters and intergroup tournaments) describe dynamics within a living system that I regard more as inevitable by- 
products of the fundamental principles that we've introduced (as per the law of association of habits).

\subsection{Conformity enforcers and diversity generators}

As far as gender roles are concerned, we are interested in conformity enforcers and diversity generators - that is, the female and the male roles respectively. Indeed, I would suggest that these first two of Bloom's elements are central to understanding gender roles, because they establish the two principle logical states of consciousness - the duality that makes cultures sustainable.

The feminine role, sustaining the known, is "static" because it is resistant to change. The masculine role, exploring at the interface between the cultural known and the unknown, is "dynamic", because it is concerned with survival, evolution and change. We might obtain a better understanding by imagining what existence would be like in the absence of one side of the equation:

(a) Without masculinity, the static in femininity would collapse into the void. Singularity going backwards, retreating from the ether - not a Big Bang, but a whimpering fizzle.

(b) Without femininity, the dynamic in masculinity would explode outwards to create chaos and disintegration.

That is, female and male, as filters of variety and producers of variety, are indispensable manifestations of being. Neither can exist without the other.

\subsection{Inner judges}

Bloom (2000: 43) describes inner judges as "biological built-ins which continually take our measure, rewarding us when our contribution seems to be of value and punishing us when our guesswork proves unwelcome or way off the mark".

Bloom's concept is important, because it coincides perfectly with what I call "the desire to be". While Bloom attributes inner judging to mechanisms based in mainstream interpretations of biology, though, I attribute inner judging to the semiotic dynamics of choice-making, that incorporate values (e.g., desires and fears) as the primal source. 
We are now in a position to explore in more detail, the mindset of the conformity enforcers.

\subsection{Matriarchal authority and relational aggression}

\subsection{Matriarchal Oppressors - enforcing conformity and the cultural known}

To provide some basic insights as to how women sustain the known, let us take a look at recent research on the nature of aggression in school children, and how it differs between boys and girls.

Lagerspetz, Bjorqvist and Peltonen (1988) showed that girls are much more likely than boys to use indirect (nonverbal, behavioral/ relational) forms of aggression against their peers.

Crick and Grotpeter (1995) introduce the idea that inflicting harm on others is done according to a shared understanding among peers of the things that matter, and that these issues of importance are different for boys and girls. For boys, the things that matter are "themes of instrumentality and physical dominance", and the strategy of physical and verbal aggression is consistent within such a context.

For girls, the things that matter most are relational issues during social interaction (e.g., establishing close, intimate connections with others), and Crick and Grotpeter (1995) discuss how girls' strategies are consistent with these different priorities. Hence, girls' attempts at harming others are more likely to be directed at relational themes, such as damaging or manipulating peer relationships, ostracizing others, spreading rumors, etc.

In a similar vein, Lagerspetz, Bjorqvist and Peltonen (1988) note that "the social structure of peer groups was found to be tighter among girls, making it easier for them to exploit relationships and harm their victims by indirect, manipulative aggression".

Consistent with the study of Lagerspetz, Bjorqvist and Peltonen (1988), the study by Crick and Grotpeter arrived at the following conclusions:

(1) Results provide evidence for the existence of relational aggression as a category that is separate and distinct from overt aggression; 
(2) Girls were significantly more relationally aggressive than were boys.

There are two other aspects of relational aggression are worth commenting on:

(1) Bjorqvist (1994) notes that indirect methods employed by girls are "socially sophisticated strategies of aggression whereby the perpetrator can inflict harm on a target without being identified".

(2) Crick (1995) shows that girls are more distressed by relational aggression than boys.

These gender differences in aggression are, more generally, part and parcel of gender differences in behavior. That is, how girls aggress has to be consistent with the greater whole that is the feminine psyche. Within this basic framework, we can explore the manner in which women oppress women, and we can infer a few things.

Whilst the known is often associated with "tolerance", it should be emphasized that such tolerance is strictly conditional, for it will not tolerate dissent. For the truth is that, for all their bonhomie, women the assumers are the enforcers of proper behavior. As sustainers of the known, women are calculating observers, always taking notes. As clingers to the known, women sum people up on their ability to conform to the known, and ruthlessly defend and assert what they believe the known should be. Femininity is the oppressive force of conformity. Women inhabit a world of shoulds and should-nots. The logic by which women oppress is based in assuming - in particular, assuming the known to be a given that is not to be challenged. You don't challenge the known - you negotiate with it, you comply with it, and you manipulate it to suit your own ends. Hence the role of "relational" aggression among girls.

Women are trapped in their world of assumptions. Rosalind Wiseman applies the compelling metaphor of a life-raft to shed light on the importance of peer pressure, and the dilemma that school-girls find themselves trapped in:

Once in the life raft she may ask herself, how did I get here? Why did I go? But when she looks around, sees that the ship [parents] is impossibly far away, the waves are too big, and there are a limited number of supplies, she quickly realizes that her survival depends on bonding with the other girls in that life raft. But your daughter isn't stupid. This realization is quickly followed by another one. She's trapped. (Wiseman 2002: 38) 
It rarely occurs to girls to leap out of the life raft and swim, or to push others off, or to assert their own rules. As Wiseman observes, it is particularly important to girls to be accepted by their peers - "There really is no choice. You stay, hope things get better, and try to survive until you're rescued. To girls, the life raft of the clique can truly feel like a matter of life and death".

Rescued by who? Boys? Marriage, perhaps?

This life raft metaphor sheds light on another interesting aspect of the female gender - fear. Rachel Simmons (2002) writes that girls are terrified of solitude, and her book explores the ways that they maintain the status quo, for fear of exclusion. That is to say, the compulsion to sustain the known is based in fear, and it impacts on other dimensions of femininity, such as fear of sex. But we'll come to that later.

Precisely as with Howard Bloom's (1995: 58) portrayal of amoeba complying during times of adversity to build themselves into a plantlike form (we will discuss this in more detail below), so too, women's fear of the unknown provides a sense of shared adversity that drives them to the conformity required to sustain the known.

Feminine oppression is relentless, and it oppresses both genders especially women. Do we not now understand why women often look to men as saviors? What is it that a woman might want to be saved from? Is it not... other women? The liberation a woman might seek from an oppressive, repetitive and demanding known is the liberation she seeks from women. For the truth is that women oppress women. Women as mothers, women as girl-friends and women as role-models create the norms against which women compare themselves and each other, judge each other, and exclude those women that dare to be different.

Women are predisposed to relying on rules. Rules provide women with some measure of control over their lives. Rules for the known are an inevitable reaction to fear of the unknown. Rules and knowing them are the key to women's survival within the life raft of culture. Hence the well-known guide for women, "The Rules", by Ellen Fein and Sherrie Schneider (1995).

Throughout her book, Simmons writes about some of the ways that girls employ rules in order to police the behaviour of girls. For example: 
There are rules, and the girl who thinks she's all that ${ }^{4}$ breaks them. They are the rules of femininity: girls must be modest, self-abnegating, and demure; girls must be nice and put others before themselves; girls get power by who likes them, who approves, who they know, but not by their own hand. Break these rules, and 'all that' looms on the horizon. (Simmons 2002: 115)

\subsection{Masculine and feminine as different logical realms}

Men inhabit the interface between the cultural known and the unknown.

When I describe the primary characteristic of femininity as sustaining the cultural known, I'm saying that women feel the constraints of culture much more strongly and they are much more committed to its ways. It goes beyond a matter of degree, because men, living at the interface between the cultural known and unknown, are provided with this something "extra" that makes their worlds very different.

An integral part of this relationship that men have with the unknown is that men are expendable. This expendability pits man against man in competition for survival. Men find themselves in more of a "do or die" situation than women, particularly in cultures that do not provide a welfare safety net for their unemployed, disabled or destitute. Women, on the other hand, while competing with other women, do so in full compliance with the cultural rules. Theirs is not a competition for survival, but for popularity. In their competition for popularity, they must assume that the opinions of other women matter, and so they must assume the known to be a given. They compete for their position on the totem pole, and in this competition, it never occurs to them to burn the totem pole.

Burning of the totem pole is the role that belongs to men. It is men who challenge the status quo, introducing new definitions and new ways of doing things.

Thus, male and female gender roles constitute different logic states, different logical understandings of the way the world is. As Simmons (2002: 126) writes, "American culture is built on dual pillars of independence and competition, values that run directly counter to the passionate intimacy, care and friendship between girls". That is,

4 "All that" is girl-speak for confidence, independence, assertiveness. 
the visible, masculine priorities of the "independence and competition" we see is runs counter to the subtle, hidden, relational priorities of Woman that grants her the power of veto.

The clash in logics between male and female create a tension that is difficult to reconcile. Indeed, there is no reconciliation, for that is why male and female exist, and why Man and Woman inhabit such different worlds. Simmons understands something of this logical contradiction:

When competition and desire cannot be enacted in healthy ways and when girls are expected to give priority to care and relationship, resentment, confusion and retribution follow shortly behind.

[...] Our culture stigmatizes assertive, professional women, casting them as cold, frigid bitches doomed to failure in their personal lives. I want to emphasize how this particular stereotype communicates to girls their worst fear: that to become assertive in any way will terminate their relationships and disqualify them from the primary social currency in their lives, tenderness and nurturing. (Simmons 2002: 127)

Here, Simmons uses the word "culture", though she does understand that this is girls (and women) doing it to girls and women "Girlhood's stigma against competition and desire can never allow girls a healthy outlet for their feelings or the kind of straightforward truth-telling to which every human being is entitled".

The implication throughout Simmons' book is that "Patriarchy" is somehow responsible for forcing women to implement relational aggression as a strategy (this is a bias that crops up frequently in other works on relational aggression). This is consistent with the feminist philosophy that disempowers women, and it stands in direct contrast to our semiotic perspective. Our semiotic interpretation provides a sound, theoretical base that empowers women, and makes them formidable agents in realizing Culture's essence.

Throughout her book, Simmons paints a picture of Woman's world where the priority for tenderness and nurturing must necessarily be accompanied by distrust, jealousy and envy and where manipulation, gossip and exclusion are the modus operandi of Woman. This is a world that is logically consistent with the priority to sustain the cultural known. Woman's world is one of hidden agendas and unspoken resentments. "Silence is deeply woven into the fabric of the female experience”, writes Simmons (2002: 3), “...During times of conflict, girls will turn on one another with a language and justice only they 
can understand. Behind a façade of female intimacy lies a terrain traveled in secret, marked with anguish, and nourished by silence".

Woman's world is necessarily secret because expressions of individuality can threaten the existence of the cultural known. Female behaviour that "sustains the known" is the cultural "glue", without which there can be no cultural unity, and no single cultural identity. Where men often group-bond within the context of a single unity of purpose in order to achieve a pragmatic outcome, women bond within the context of a single unity of (cultural) being, beyond which existence is unimaginable. Hence, Simmons writes that, "As we have seen, girls experience isolation as especially terrifying. Since girls earn social capital by their relationships with others, isolation cuts to the core of their identities. For most girls there is little more painful than to stand alone at recess or lunch".

Woman's fear is legitimate. Woman's pain is legitimate. Men's expendability is a demonstration that the unknown is a dangerous place. So even though women are exempt from having to confront the dynamism of the unknown, they are right to still fear it - indeed, they should fear it all the more, because they never get to embrace it. Women are right to feel the terror of exclusion and solitude.

Human females bond by sharing intimacies and secrets interpersonal transactions that have the effect of enforcing conformity and unity. Parallels with these dynamics exist in the animal kingdom. I am reminded of a David Attenborough documentary on a colony meerkats. This was a viciously matriarchal colony. The intimate bonding between all the female meerkats within this colony was captured in a scene of a matriarchal group embrace so tight that they coalesced into a loving, hugging, cohesive clump of faces with eyes staring out. But not the entire colony - one of the females was excluded. She was hounded and marginalized by the entire group. Viciously picked on and pushed to the margins, her very survival was at stake.

Unlike meerkats, human girls would not be caught treating an "odd girl out" in this overt manner, primarily because it is not what "nice" girls do ("niceness" is a measure of popularity, which is the yardstick of relational success). They would prefer, instead, to strangle her soul so that no-one might see the blood on their hands. The analogy is complete. The meerkat expelled, brutalized and left trembling in the fetal position at the margins of the colony is the same as the "odd girl 
out", devoid of self-esteem, not knowing where to turn, not knowing who might save her.

Within meerkat culture, females tend to stay within their colonies, whereas males can roam to new territory. If a male is accepted by a female within the new colony, he can call the new colony home. The female meerkat that is hounded to the margins, on the other hand, has no such freedom. The female condition, in being "safe" and "provided for" within the meerkat matriarchy, is hell when excluded by the matriarchy. The terror in the eyes of the victimized female meerkat is the same terror of solitude that is Woman's.

What a compelling metaphor that Meerkat Matriarchy provides for Girl World as painted by Simmons and Wiseman. Some of the case studies of exclusion and "clique expulsion" that Simmons relates are analogous to what happened to the excluded, terror-struck meerkat. For example, Simmons relates the story of Erin, who began at a new school as a confident and effusive girl who easily made friends, only to suffer an unrelenting "clique expulsion" that saw her becoming withdrawn and suicidal. Her transgression? Confidence. What the other girls defined as "all that". It was other girls, not boys, who utterly destroyed her self-esteem.

Where the meerkat females cling to one another in tight, physical embrace, "girls cling tightly to one another to know, as one told me, 'that we're not crazy", writes Simmons (2002: 101).

This then, explains something of the role of Woman and her trials and tribulations. Sustaining the known and its accompanying fear of the unknown pull inwards, to predispose Culture to the static, brutal conformity of a beehive. Masculinity provides the key to Culture's liberation from stultifying, beehive conformity. Men are more often the liberators of women, not their oppressors.

We can now understand something of the instinct that has, throughout history, compelled men to "save" women. It is the subconscious awareness - a "sense" that men often have - that a woman cast adrift is exposed to a terrifying world. Within marriage, a woman need never again concern herself with clique expulsion. Not only does marriage provide her with the status of normality, but it provides a life-raft should she ever experience a falling-out with her peer group. Marriage liberates a woman from the be-all and end-all that the clique has played throughout her life. 
And we obtain a clearer sense of the nature of human sexuality, and how the two sexes interact with one another. Femininity gets its thrill from luring and teasing at the fringes of an urgent, throbbing and dangerous masculine unknown. Within the shadows that define the contours of the feminine psyche, a woman is drawn to the mysterious, unpredictable masculinity that can protect her or destroy her.

A woman's fear of sex is inextricably connected with the thrill of the forbidden, of transgressing the rules of the cultural known. Woman's fear of sex and her fear of breaking the cultural taboos are the reasons that most cultures default to the predisposition of Man as the pursuer, Woman as the pursued. This pair of dynamics provides the basis for Woman's power of veto.

\subsection{The power of veto, sexual selection and violence}

In biological terms, Woman's power of veto is expressed in terms of sexual selection. Bloom observes:

[...] women are violent. In fact, females are as much a part of the apparatus that triggers male violence as the men themselves. Nobel Prize-winning ethologist Konrad Lorenz described a common behavior in several species of ducks. The female runs out to the edge of her husband's territory and tries to provoke another duck, then runs back to her male, stands next to him, and looks behind her at the enraged rival in the hope that her mate will jump into the fray. Many are the human females who have tried to stir up a similar fight. (Bloom 1995: 33)

Bloom continues, "Women encourage killers. They do it by falling in love with warriors and heroes. Men know it and respond with enthusiasm". Men perpetrate violent acts knowing full well "how the damsels back home would admire their bravery".

So let us not be swayed by the "invisibility" and silence of the female role, which is an expression of their power of veto. For all the terrible things that men have done throughout history, we see that men's deeds were also the dirty-work of women, who have always been too comfortable in the security provided by men, to be bothered to do it themselves.

In biological terms, the power of veto is expressed in terms of sexual selection. Bloom observes: 
The females of a species develop a craving for a certain kind of guy, and all the males compete to live up to the female ideal. Lady peacocks adore hunks with towering blue tails, so peacock gentlemen sport foppish plumes. Lady bowerbirds swoon over bachelors with an architectural flair, so bowerbird males turn sticks and scraps into the Taj Mahal. And what have human females gone for in nearly every society and time? 'Courage' and 'bravery'. In short, violence. (Bloom 1995: 33)

\subsection{Gender roles among animals}

The relationship between the known and the unknown can be observed in non-humans. For example in David Attenborough's documentary "Echo of the Elephants", a female elephant in oestrus plays coy, running away from the advances of Dionysus, a magnificent beast to whom other male elephants respectfully defer. Dionysus had briefly emerged from the jungle's unknown, to enter into the world of the matriarch-dominated tribe, before returning again as mysteriously as he had arrived. Apart from these occasional encounters, the male elephant is a solitary brute spending most of his time wandering the jungle alone. The females, on the other hand, travel together in a close-knit group, under the leadership and protection of a matriarch.

And the black-widow spider (female), in many respects seems to have evolved behavior that, in the context of the known and the unknown, is more male. And the supposed male black-widow, behaving more as a female in human terms, surrenders its very life to the thrill of being taken in the dangerous act of procreation.

And if, as feminists (such as Germaine Greer) mock, a traditional woman's role is nothing more than that of "life-support system for a womb", then perhaps they might spare a thought for the poor male anglerfish, who finds ultimate fulfillment in life as nothing more than a "homing device for testicles". For once a tiny male locates a roaming female and attaches himself to her, he (along with several other males) is provided for for the rest of his life, through nourishment provided from the giant host's body. Thus, without ever having to fend for himself again, he atrophies to the point where only his testicles remain as viable organs. In being set up for life with an endless supply of nourishment, he has fulfilled his objective in sustaining his known world. And with her many parasitic, non-communicative 
partners, the female becomes, for all intents and purposes, a kind of hermaphrodite.

With these examples, we see that the male and female "roles" (whatever they are) can be reversed when we define things in terms of the known and the unknown. Is it more correct to think of the physiologically male black-widow spider and anglerfish as psychologically female?

While we are on the topic of gender roles in animals, recent discoveries in neuroscience - for example, Douglas Fields, R. (2004) suggest that there are two poles of behaviour, analogous to sex roles, in the brain. Neurons seem to play the more active role, while glial cells seem to play the more mediatory, "facilitative" and nurturing role (sustaining the known).

\subsection{Fear of sex}

The females of such species of animals as elephants, badgers, meerkats, dogs and cats... and humans, all appear to experience elements of both fear and excitement in sex. So do some male creatures such as black-widow spiders. Some female animals, such as bonobos, throw caution to the wind and eagerly submit to it in the course of social rituals.

\subsection{The role of fear}

Sustaining the known is associated with fear. Fear of the unknown. Fear predisposes to unity and cooperation. Courage predisposes to freedom and individualism. Bloom writes:

Superorganisms exist even on the very lowest rungs of the evolutionary ladder. Slime mold are seemingly independent amoeba, microscopic living blobs who race about on the moist surface of a decaying tree or rotting leaf cheerfully oblivious to each other when times are good. They feast gaily for days on bacteria and other delicacies, attending to nothing but their own selfish appetites. But when the food runs out, famine descends upon the slime mold world. Suddenly the formerly flippant amoeba lose their sense of boisterous individualism. They rush toward each other as if in a panic, sticking together for all they're worth. 
Gradually, the clump of huddled microbeasts grows to something you can see quite clearly with the naked eye. It looks like a slimy plant. And that plant — a tightly-packed mass of former freedom-lovers - executes an emergency public works project. Like half-time marchers forming a pattern, some of the amoeba line up to form a stalk that pokes itself high into the passing currents of air. Then the creatures at the head cooperate to manufacture spores. And those seeds of life drift off into the breeze.

If the spores land on a heap of rotting grass or slab of decomposing bark, they quickly multiply, filling the slippery refuge with a horde of newly-birthed amoeba. Like their parents, the little things race off to the far corners of their new home in a cheerful hunt for dinner. They never stop to think that they may be part of a community whose corporate life is as critical as their own. They are unaware that someday they, like their parents, will have to cluster with their fellows in a desperate cooperative measure on which the future of their children will depend. (Bloom 1995: 58)

Clearly, amoebae are courageous, daring individuals when times are good, racing off to the far reaches of their immediate environment, exploring and feasting. When times are bad, they congregate into colonies of conforming, well-behaved individuals who cannot afford to rock the boat, because their survival depends on it.

This has its parallels with what humans do. But with a twist. While for amoebae, there exists a sharp delineation between good times and bad which predisposes them to individualism or group conformity, in humans, the cultural dynamics are based primarily on the delineation between the known and the unknown, with predispositions to one or the other based in gender roles.

Woman's power of veto defends against whatever might threaten the order that makes cultural unity possible. And so "fear" is an inextricable aspect of the female condition. Fear of novelty, fear of change, fear of sex, fear of losing control and fear of losing her place on the life raft.

Fear of sex (e.g., sex as forbidden) has an important part to play in women's enjoyment of sex in all its dimensions, in the thrill, the intimacy, the rituals and the fashions. Even though healthy women regard sex as enjoyable and necessary, men must still pay, in one form or another, because women have to be enticed beyond their fear that constrains them. Indeed, men paying for sex can itself constitute a part of the thrill.

What is there to fear about sex? Do animals fear sex? On occasion, it would appear that elephants certainly do — refer to my preceding 
discussion about the female elephant playing coy and running away from the male elephant. Might this not suggest fear on the part of the female?

In another documentary by David Attenborough on meerkats, similar dynamics were evident. Meerkats comprise a tight-knit colony (mob) of five to thirty or forty members, headed by one alpha male and one alpha female. In small colonies, only the alpha female is allowed to mate with the alpha male. In larger colonies, subordinate females tend to initially repel approaches by males. Female meerkats are usually philopatric (tending to remain within the one territory), while males often leave the mob to join another. During Attenborough's documentary, one such male had approached the territorial boundary of another mob of meerkats, and it was interesting to observe the female, who was behaving secretively - she seemed to be indecisive about whether or not she should take up this illicit affair.

And there is our example of the redback spider. Is the male spider aware of the risk it is taking? Is there something masochistic in its behaviour? Does it derive an ultimate thrill from the fear of submitting to the female that is somehow analogous to submission by women to men?

Not all animals appear to have "issues" with sex (on the surface). Bonobo monkeys for example. And female seals seem to be indifferent to mating with the dominant male, though since nobody's asked them, perhaps this is unfair. But among those animals where sexual "issues" are evident, such issues do seem to involve some kind of dynamic with fear and, perhaps, even some component of the forbidden. Which raises interesting questions about human notions of morality.

In having observed these parallels with the animal kingdom, we might now infer that resistance by female humans, implying fear, is part of something primal associated with being. We must surely ask ourselves, what is there to be afraid of?

\subsection{The cultural known - why it is so important}

So what's the big deal with this known that men must contend with, and that women are reluctant to let go of? 
Before modern liberalism, the "known" in which a woman felt secure revolved around the parents that raised her. Furthermore, her parents never taught her to be independent and self-sufficient - not because they were selfish and thoughtless, but because independence and self-sufficiency requires a logical mindset that is contrary to the priorities of motherhood.

With the advent of sexual freedom, however, men have to contend with a new Woman's known... the ever-present boyfriend/partner. In today's loose morality of sexual freedom, women tend to transition across relationships rather than risk solitude for any length of time, and so they need an incentive to be lured away from an established and secure known. What women interpret as love on their part can often be nothing other than need motivated by fear - specifically, fear of solitude. Better the devil you know than the devil you don't know. An established provider who has demonstrated his willingness to stick around is better than any untested temptations that might present themselves. Thus in today's climate, women's relationships can often be based less in love or moral obligation than in fear of solitude, manifesting most commonly in peer pressure. Where before, parents were the anchor that provided their daughter with the basis for resisting change, today it is the ever-present boyfriend whose commitment she wears as a badge to assert her normality.

Yet other truths remain unmistakably in their original form. When a woman turns to a man to be saved by him, there is something in her nature as Woman that has legitimate reason to fear that which has her turn to him for protection. When she plays infuriatingly coy she's not always pretending. She really does not want him to intrude into her current status quo and she does fear the change that he is threatening to bring to her life. When she says "no" she really might mean "no"... except that another part of her might mean "yes" — the part that wants change and wants him, but she fears surrender and losing control. If it is true that Man fears commitment, then it is equally true that Woman fears falling in love. Both are the same types of fear expressed from the perspective of the pursuer versus the pursued.

Of course there is nothing new in these observations in and of themselves. They have been observed and discussed since Homo sapiens first started etching on cave walls. What is new is our theoretical framework based in semiotics, shedding light on the powerful predispositions based in the mind-body relationship. These 
differences between men and women are neither coded in the genes ("Nature") nor are they arbitrarily socialized ("Nurture"). These differences subscribe to some entirely different, basic and universal laws common to every living organism.

And so in spite of all our muddling around with the Nature/Nurture debate, the more things change, the more they stay the same. Women continue to prioritize the cultural known. They continue to resist and men continue to initiate. Women continue to be asked out and men continue to pick up the tab. Women continue to be provided for and men continue to pay.

Sexual freedom is not freedom at all, because we must all still contend with a cultural known that remains the principle domain of Woman. Moreover, sexual "freedom" has simply presented us with new constraints, limitations and yardsticks by which we judge each other. For example, while divorce has lost much of the stigma that existed before feminism, it has established new standards to force us to keep up with the Joneses. Whatever we make of divorce today, the simple fact is that divorced men have at least "arrived". They have gone through a rite of passage that has confirmed their transition into manhood. Their complicity - the chumphood that characterizes Modern Manhood — has almost become mandatory as a rite of passage.

Before feminism and the accompanying sexual freedom, parents provided a source of comfort and guidance for their children. Today, as Judith Harris (1998) attests, peer pressure reigns supreme over parental influence. For the truth is that peer pressure provides an oppressive zeitgeist with shoulds and should-nots that are often more puritanical and stultifying than anything dreamt up during the Victorian era.

\subsection{Conferencing for consensus}

As we've observed, Men and women are to Culture what neurons and glial cells are to Mind. And just as we are now beginning to realize the crucial facilitative and networking roles that glial cells play in the emergence of Mind, so too, we need to realize the crucial facilitative and networking roles that women play in the emergence of Culture.

As we've established, women are, first and foremost, the assumers of cultural norms, while men derive their understanding of reality 
through making choices at the interface between the cultural known and the unknown.

The choices that men make are visible and the consequences are immediate and self-evident. Often, it is a potentially dangerous world where the choices that men make can kill them right where they stand (certainly in what Warren Farrell (1994) describes as the "death" professions, such as mining, construction, rescue, war, etc.).

Women, on the other hand, derive their understanding of reality through making choices from within the cultural known. They conference, network, gossip, discuss, agonize, working themselves into a lather to construct edifices that owe their existence to consensus. Feminism is a product of just such a process. And the original feminists have recruited the agents of Woman's bidding (i.e., men) in order to actualize the feminist reality by way of changing the various structures (e.g., political), in order to make real that which began as bubble and froth in the minds of a handful of women in conference.

Women must be seen to uphold the cultural known. Thus the methodology of Woman is stealth - flying beneath the radar in order to avoid detection. This is why manipulation, gossip, exclusion and all those other things that we've identified as relational aggression are so important to women. So successful is Woman's methodology that the success of feminism itself can be attributed to it.

It is important to realize that conferencing for consensus is not a trivial role. It is the very glue that binds Culture together into a shared knowing, in exactly the same way that glial cells bind the brain together into a single consciousness.

Gossip is an important aspect of "conferencing for consensus". Chesler (2001: 154) writes, "Thus gossip reinforces traditional morality, solidifies group identity, excludes 'outsiders', and serves as a warning that one may become the focus of gossip if one behaves antinormatively. Gossip reinforces patriarchal ethnic and class solidarity".

Chesler describes the way that women monitor the behaviour of women through gossip, and refers to the work of anthropologists Ilsa M. Glazer and Wahiba Abu Ras (on the relationship between "honor" killings and gossip), quoting their conclusion that: "Women's gossip creates the climate in which the [honor killing] of a young woman is inevitable" (Chesler 2001: 161).

Gossip is one manifestation of a particular type of personality trait that is logically consistent with "sustaining the known" and con- 
formity. Envy is another manifestation of that trait. Envy - you want what everyone else has. Women's magazines appeal to women's proclivity for gossip and envy. Women's magazines intrude into the personal lives of celebrities, building them up or tearing them down. They feed women's passions for knowing who's going out with whom, who's doing what to whom, who's wearing what, who's been caught without wearing makeup and a whole lot more. They provide fashion tips and advice on relationship and sex issues, thus tapping into the priority that women place on observing the shoulds and should-nots of proper social conduct. Women's magazines provide an important means by which women conference for consensus.

So important is conferencing for consensus to women that even the men they choose are a product of it.

\subsection{Relational aggression and the men that women choose}

Women choose the types of men that they would like their sons to be. In this simple aphorism, we can obtain some sense of how far the tentacles of Woman's power can reach. Women as the nurturers of little boys and the choosers of men possess power far more extensive than is suggested in the myth of disempowerment preferred by feminists. Much of this power is based in relational aggression enforcement of the norms by which women judge women and the choices they make in men.

Wiseman points out that girls' behaviors in peer groups are so completely proscribed that they define even their choice of boyfriends. They turn to their cliques not only to define the "right" boys, but also to decide on relationship issues, such as whether or not a boyfriend should be dropped.

Wiseman asked boys what they wanted to know about girls. Interestingly, she observes that the "right" boys are often assholes (her choice of word):

Why do girls like assholes [boys often ask]? Girls' reason: Because he's hot and they can be really cool when they're alone. My [Wiseman's] reason: The asshole fits in the "Act Like a Man" box. He's the Misunderstood Guy who looks like he has things under control. Girls find it especially attractive if the asshole shows them his sensitive side and only they can understand him. (Wiseman 2002: 186) 
In these sorts of examples, we see an interesting pattern unfold. Not only do girls oppress girls in the norms that are embodied in their shoulds and should-nots, but they also identify the norms by which boys are judged, the norms that become women's preferences.

From Wiseman's work, we see that girls (and women) play an important role in actively nominating the male stereotypes that other girls (and women) should choose. If popularity is so important for girls within girls' cliques, then it follows that popularity is also the yardstick with which girls assess boys. Popular girls identify the popular boys whom other girls should be seen with, if a girl is to have any hope of competing on girls' totem poles. Why do girls choose bad-boys? Now we know the answer.

Many a man has experienced that peculiar tendency in women to be especially attracted to them if they were "spoken for" (married or in an established relationship). The tendency has been for men to dismiss this increase in female interest as a function of their increased self-confidence that makes them shine in the presence of their partner. In part at least, maybe that's true. But a more compelling factor, in light of our discussion, is that women rely on the opinions of other women to define values, and a man that is spoken for must surely have something going for him. It sounds too simple and obvious. This perspective sheds light on the mysterious choices of many women throughout history, on their proclivity to choose married or attached men, and on their willingness to play second fiddle within polygamous relationships and harems. What is it that can make a married man attractive to many women? The fact that he's married, in and of itself, is oftentimes a sufficient enough condition. More generally, though, marriage is also a marker for success, and a successful man within a relationship will understandably be especially marketable.

All these observations have serious implications for feminism. The sexists and abusers that feminists complain about are the bad-boys and philanderers of women's own choosing.

Women learn from other women (namely, their peers - but also, their mothers... and the fathers that their mothers choose) what the "right" types of men are. While we are in the spirit of thinking systemically, let us take this a step further. Women choose the types of men that they would like their sons to be. Can we now see the wider, systemic implications? Woman's role is important not only in 
the types of men that are chosen in the here and now, but also in the types of men that make it into the next generation.

\subsection{Summarizing the implications of relational aggression}

(1) Women, not men, are responsible for women's low self-esteem;

(2) Success in men is based on competition and control. Success in women is based on connectedness and popularity, and this provides the basis for the relational aggression that manifests itself as peer pressure among women;

(3) Relational aggression plays an important role in how women impact on the types of men that are chosen to become cultural stereotypes.

\subsection{To conclude}

Thus far, we've gone through the theory, to understand gender roles in terms of two types of habitual ways of looking at the world. That is, the known (femininity) and the unknown (masculinity). The "known" is a cultural attractor that predisposes to conformity, while the "unknown" is a cultural attractor that predisposes to dynamism and variety. It makes good, common sense. There are many more "types" of men than there are "types" of women. The bell curve probability distribution for men's behaviour is very much wider than that of women, and this is reflected in intelligence, crime and other behaviour/psychological characteristics.

Let us explore in further detail, what it is to "feel" the female type of knowing.

\subsection{Getting inside the minds of women}

\subsection{The need to infer}

This brings us to contentious, uncharted territory where the only mode of analysis available to us is inference, based on what we know about Dasein and the law of association of habits. Why must we rely on 
inference? Couldn't we simply ask women about their experiences? Weininger provides an idea of what we are up against. He begins his chapter "Male and Female Sexuality":

'Woman does not betray her secret' (Kant). 'From a woman you can learn nothing of women' (Nietzsche).

By psychology, as a whole, we generally understand the psychology of the psychologists, and these are exclusively men! Never since human history began have we heard of a female psychology! None the less the psychology of woman constitutes a chapter as important with regard to general psychology as that of the child. And inasmuch as the psychology of man has always been written with unconscious but definite reference to man, general psychology has become simply the psychology of men, and the problem of the psychology of the sexes will be raised as soon as the existence of a separate psychology of women has been realised. Kant said that in anthropology the peculiarities of the female were more a study for the philosopher than those of the male, and it may be that the psychology of the sexes will disappear in a psychology of the female.

None the less the psychology of women will have to be written by men. It is easy to suggest that such an attempt is foredoomed to failure, inasmuch as the conclusions must be drawn from an alien sex and cannot be verified by introspection. Granted the possibility that woman could describe herself with sufficient exactness, it by no means follows that she would be interested in the sides of her character that would interest us. Moreover, even if she could and would explore herself fully, it is doubtful if she could bring herself to talk about herself. I shall show that these three improbabilities spring from the same source in the nature of woman. (Weininger 1906: 85-86)

Any man who has sincerely questioned women directly or indirectly, in order to understand how they think, will realize the futility of such a task. As women speaking from a perspective that has women's reality as a reference point, they can never present their answers from any other perspective that might otherwise bring their answers into sharp relief. What makes it even more difficult is that women don't understand women. They live in a world of assumptions, much more so than men, and what they know about other women they are more likely to have learned by following and imitating, rather than challenging or questioning. 


\subsection{Sex and character — Otto Weininger as semiotician}

What is this "science of character", to which Otto Weininger refers as "characterology", if not semiotics?

[...] Is there in a man a single and simple existence, and, if so, in what relation does it stand to the complex psychical phenomena? Has man, indeed, a soul? It is easy to understand why there has never been a science of character. The object of such a science, the character itself, is problematical. The problem of all metaphysics and theories of knowledge, the fundamental problem of psychology, is also the problem of characterology. At the least, characterology will have to take into account the theory of knowledge itself with regard to its postulates, claims, and objects, and will have to attempt to obtain information as to all the differences in the nature of men. (Weininger 1906: 81)

\subsection{The need for a female psychology}

Otto Weininger (1906) had begun a fascinating and important (urgent) foray into the relationship between sex and psychology. Importantly, as he had identified, what we knew back then within the field of psychology was actually male psychology. Sadly, to this day, the situation has not been satisfactorily resolved. The field of psychology remains essentially from a male perspective. If we think that today the field of psychology has become more female, it is only because feminism has compelled women to become more male (women can do anything that a man can do) and the subsequent androgenization of society has resulted only in a perpetuation of the male perspective. We remain without insight into the nature of psychology and its relation to sex.

However, it is worth noting that recent books that have come onto the market on relational aggression (e.g. Chesler 2003; Simmons 2002; Wiseman 2002) are beginning to probe the inner workings of the female mind, to the extent that it might herald the very female perspective that is needed.

Weininger proposed that women think in "henids". According to his definition, a henid is an aspect of psychical data, perhaps best described in the context of "feelings" or emotions, before it becomes a fully fleshed out idea. While Weininger's definition of henid is not as precise as it could be, it nonetheless points to key differences in the ways in which men and women think. 
According to the law of association of habits, however, thoughts are habit-associations, and women's henids must conform to this semiotic perspective. A more precise definition, therefore, is that henids are thought processes (habit-associations) that are more contextual than men's thought processes — assimilating many cues (associations) to arrive at a "feeling" or sense as to what is going on, before understanding the specifics. Men's thought processes, on the other hand, must apprehend and commit to facts with some element of immediacy and urgency, for example, in order to compete with an opponent or construct bridges that work. Accordingly, the contexts for men's thought processes are based on the practical application of facts at hand, while the contexts for women's thought processes are more "big picture". What men gain in their apprehension and application of specifics they lose in the big picture, and what women gain in their apprehension of the context of things, they lose in practical application.

\section{Weininger described henids as follows:}

Now what is the relation between the investigation I have been making and the psychology of the sexes? What is the distinction between the male and the female (and to reach this has been the object of my digression) in the process of clarification?

Here is my answer:

The male has the same psychical data as the female, but in a more articulated form; where she thinks more or less in henids, he thinks in more or less clear and detailed presentations in which the elements are distinct from the tones of feeling. With the woman, thinking and feeling are identical, for man they are in opposition. The woman has many of her mental experiences as henids, whilst in man these have passed through a process of clarification. Woman is sentimental, and knows emotion but not mental excitement.

[...] It is certainly the case that whilst we are still near the henid stage we know much more certainly what a thing is not than what it is. Instinctive experience depends on henids. Naturally that condition implies uncertainty and indecision in judgment. Judgment comes towards the end of the process of clarification; the act of judgment is in itself a departure from the henid stage.

The most decisive proof for the correctness of the view that attributes henids to woman and differentiated thoughts to man, and that sees in this a fundamental sexual distinction, lies in the fact that wherever a new judgment is to be made, (not merely something already settled to be put into proverbial form) it is always the case that the female expects from man the clarification of her data, the interpretation of her henids. It is almost a tertiary sexual character of the male, and certainly it acts on the female as such, that she expects from him the interpretation and illumination of her thoughts. It is from 
this reason that so many girls say that they could only marry, or, at least, only love a man who was cleverer than themselves; that they would be repelled by a man who said that all they thought was right, and did not know better than they did. In short, the woman makes it a criterion of manliness that the man should be superior to herself mentally, that she should be influenced and dominated by the man; and this in itself is enough to ridicule all ideas of sexual equality.

The male lives consciously, the female lives unconsciously. This is certainly the necessary conclusion for the extreme cases. The woman receives her consciousness from the man; the function to bring into consciousness what was outside it is a sexual function of the typical man with regard to the typical woman, and is a necessary part of his ideal completeness [...]. (Weininger 1906: $100-102$ )

These are important ideas and within them, is the seed of an important realization. However, whilst Weininger is referenced throughout this paper, we need to qualify his notion of henids. That is, thinking in henids is not to be considered inferior to the more analytical, deductive reasoning that we are more likely to attribute to men. To begin with, thinking in terms of henids has more in common with lateral/ systemic thinking - leaving things undefined until a more complete context emerges, and upon which a different kind of important and informed decision can be made.

Weininger's reference to henids is related to the choices that men and women make. The gender that is provided for will have different thought processes to the gender that provides (as a natural expression of the law of association of habits). Therefore it is only to be expected that the gender that does the providing will be able to conceptualize things more analytically, while the gender that is provided for will be exempt from the requirement to do so. The promise of motherhood grants women that privilege, because it provides them with an escape hatch that liberates them from the unconditional requirement to provide for and support anyone. That is, if women are more inclined to think in henids, it is because they can, not because henids constitute an integral aspect of the female condition that is supposedly set in the concrete of the genetic blueprint. 


\subsection{Cultural constraints on thought}

We are all constrained by the options provided to us from our cultures, and our desires that are shaped by these options. Whether male or female, we cannot go beyond those options, because our culture will exclude us and deny us the things (jobs, friends) that are essential to our survival. Whether male or female, complicity is essential, or we will die. But complicity comes in two forms - male and female. The gender that is provided for has different priorities, different ways of thinking. The gender that provides must apprehend more uncertainty and risk.

Yet, insofar as male and female constitute very different ways of thinking, we should regard them as different manifestations of the one entity - Culture. Inevitably, male and female have a shared cultural logic about the way things are. And so men and women must remain both divided in their sexual natures and united in their cultural assumptions.

We might now begin to see something of the basis for Weininger's henid theory. Women are predisposed to desiring lifestyle choices (from Culture) that predispose them to thinking in terms of henids.

\subsection{Defining and assuming}

So far, we've covered the more self-evident and immediately visible aspects of how men and women differ in their thinking. But there is a deeper aspect that we need to look at, in order to account for why men are more likely to commit to an idea or cause, while women are less likely to.

Thinking in terms of henids is related to assuming and imitating. Women play a particularly important role in maintaining cultural memes (and hence, cultural values and traditions).

The main difference between the psychologies of men and women might be best explored in the context of defining versus assuming.

Assuming does not define anew, but rather, asserts the definitions that have been made, without necessarily possessing a comprehension of the manner in which the definitions were derived.

As men are thrust into having to deal with the unknown, they must learn to confront and apprehend problems they encounter. They must strive to understand the issues that impact on their survival, and they must define problems and their solutions. Women, whose priorities 
are based in sustaining the known, do not experience the same level of compulsion to have to deal with such demands.

Men are more likely to understand, to some level, the workings of stereo systems, computers and technology. Women are much less likely to do so, and they are more content to regard the technologies they use as black boxes, the inner workings of which are irrelevant to their world view.

Even if a man is not "technologically aware", he will nonetheless possess a way of looking at black boxes "rationally", in the sense that implicit in his mind is a rational explanation for their inner workings. For women, the inner workings of black boxes remain mysteries that can be safely disregarded as irrelevant to their own priorities. For women, black boxes are a "given" that can be safely taken for granted just as, for them, cultural reality is taken as a "given", not to be questioned or challenged.

With rationality comes confidence, for the truths that are learnt by doing, questioning and confronting, will be more inviolable than the truths that are learnt by assuming. Women, however, as sustainers of the known, are precluded from exploring the possibilities that might otherwise provide a fertile ground for confidence to grow. Content to be provided for, they cannot possibly get to discover the full range of their potentials, and what they sometimes might feign as confidence is quintessentially a brittle, fragile arrogance - and every bit subject to the whims from outside influences. It is a woman's prerogative to change her mind

Ultimately, when women enter politics, run businesses or fix stereo systems, they do so as assumers, not as problem solvers. Women can and do, for example, run businesses every bit as competently as men. But, consistent with their role as sustainers of the known, they will be most successful in established, stable businesses focusing on relationships, rather than dynamic, risky businesses characterized by individualistic leadership. Sustaining networks, procedures and protocols are most amenable to the ways of women.

In the context of the relationship between the known and the unknown, we can now understand why women are more likely to be interested in astrology, history and the arts (not "art" as creation but "arts" as appreciation of creation), while men are more likely to be interested in cars, philosophy and science. 


\subsection{The motivation to define or to assume}

What woman, inundated with offers to be taken care of, whether by parents, or men, or government (today, we have government-asprovider), would shun all possibilities in the pursuit of elusive and illdefined higher ideals?

Men have no such luxury. They are forced into situations of competition and confrontation, and defining for men is a matter of survival. Whilst Government provides also for men, such as the unemployed, such a lifestyle is generally not a sought out option. Unlike unemployable women on social security benefits, unemployable men, without any cause to believe in or purpose to inspire them, are not even remotely viable propositions for marriage.

Women assume because they can. Men define because they must. Women think as women because they can. Men think as men because they have no choice.

How then, might a woman obtain the motivation to live the logics of defining? How difficult would it be for a woman to completely abandon any suggestion that she can, one way or another, rely on men? Would not a heroine along the lines of Joan of Arc, no matter how courageous and determined she might be, experience a world of vastly different options to that of men? Should we not admire such a heroine all the more for having chosen the difficult path, in the face of all the privileges that are her birthright that she has chosen to reject?

For a woman to deliberately choose the more difficult path and throw away all her feminine privileges would seem to be extraordinarily foolhardy. Yet if she is to move in any way towards the disciplined rationality of men, then that is precisely her only option. The ever present, culturally sanctioned logic permitting women to be stay-at-home mothers liberates women fully from commitments to ideas, goals and careers as matters of life and death. Women have more freedom to pick and choose and in this light, it is almost impossible for a woman to take on the world in a can-do spirit of determination and courage.

For this freedom to pick and choose, women pay a price. The options that make life so easy for them become the needs by which they define their values. If a woman considers herself bored by her womanly privileges and being taken care of, we can predict with certainty her experience of the terror of solitude and the collapse of 
her world, were she suddenly deprived of the privilege of being provided for that she had become accustomed to.

The relationship between the unknown and the known, in terms of the defined and the assumed, is reflected in the manner in which a hero might emerge from a culture. Traditionally, the hero will not seek to accommodate women's desires but rather, assert new standards.

And so in the context of modern feminism, women are constantly changing their definitions as to how they want their men to be, constantly perplexing the men that try to meet their demands. And yet the truth is that women don't know what they want, and men are wasting their time in trying to accommodate their demands. With today's feminism and the subsequent tendency to role reversal, neither men nor women understand that it is not the woman's priority to define nor the man's priority to accommodate.

\subsection{Women's ways of knowing}

Here are a couple of famous quotes by Anaïs Nin that capture the essence of feminine logic, in the context of the tension that exists between the known and the unknown. ${ }^{5}$

And the day came when the risk to remain tight in the bud was more painful than the risk it took to blossom.

And, from The Diaries of Anaïs Nin:

Throw your dreams into space like a kite, and you do not know what it will bring back, a new life, a new friend, a new love, a new country.

Do these quotes not embody the essence of the psychology of women? Do they not invite women, simply, to "turn up"? Don't they suggest that it is a woman's prerogative to rely on men? For a woman, there is no slaying of dragons, no overcoming of an adversary, no victory in the face of great odds. She simply has to be there. While this demands its own form of courage (after all, a woman can give birth to a bad

5 I was unable to locate the original published sources of these quotations by Anaïs Nin. 
choice), the contraceptive pill has freed modern women from such immediate responsibilities.

Whilst Nin's aphorisms might also be applicable to men in some contexts, they are inconsistent with the dominant masculine paradigm. It is not stereotypically masculine thinking to cling to the known for fear of the unknown. Nor is it stereotypically masculine thinking to surrender with abandon in the hope of being saved or stumbling upon good fortune.

And this brings us to the sexuality of men, and how it most perfectly complements the sexuality of women. For if, as Anaiis Nin insists, the longing to be violated is a secret, erotic need in a woman, so too, it should be understood that the urge to violate is a not-sosecret compulsion that must be curbed in men.

\subsection{The phenomenology of the known and the unknown}

Assuming and defining are related to the cultural known and unknown. Here we deal with being, before any condition of being is defined. What I am alluding to here is a resolution of the conflict between nothingness and being. The natural state of "being" is, of course, not being... and this is reflected in the remark, commonly made by philosophers and scientists alike, "why must there exist anything at all?" Surely the most basic state of existence, is nonexistence, and so why should all this complexity emerge at all? Is not the simplest, least energetic, most stable existence an empty universe, a black void, non-existence? We shan't venture into the phenomenology of quantum physics. However, it is important to consider what phenomenology might imply for gender roles.

The moment that a state of being is defined, a state of non-being is also defined. A state of being must contend with the events that threaten it. But a condition of stability, on its own, will drift towards stagnation and collapse as it seeks the easiest, least energetic path (that's why the male anglerfish's ultimate tendency, as discussed earlier, is to become a pair of testicles). The only way that a state of being can evolve to anything more complex, is to factor into its existence the dynamics of change. But here, we have a dilemma, for the dynamics of change are logically inconsistent with the dynamics of sameness and stability. Human and animal existence resolves the 
dilemma through gender roles. Any state of being must desire to be, and the state of being that emerges will need to be consistent with the ecology within which it finds itself. Thus, the gender that has it so easy will automatically be predisposed to one type of logic based in sustaining the known, while the gender that has it so hard will be predisposed to logics based in exploring the unknown. And within their shared ecologies, male and female co-exist with their logically contradictory predispositions.

Clearly, what this implies is a process view of life and being. And so what we have come to is a phenomenological account of gender roles expressed in the context of being and non-being, where gender roles can be understood from the following perspective:

(1) Masculinity, on its own, leads to chaos and disintegration;

(2) Femininity, on its own, leads to stagnation and collapse.

Thus we have the mechanism by which cultural habits are modulated with masculinity being the agent of change, and femininity providing the resistance to change.

\subsection{Psychology as Men's Psychology}

Our preceding analysis suggests a new kind of psychology that factors in both male and female. This contrasts with the psychology that has dominated the mainstream.

As Weininger (1906) pointed out, frequently men pioneer a field such as psychology, in the belief that they have hit on general, human principles that apply to both men and women. But typically, the reality is that they've developed a male perspective that is ignorant of the very different ways of women. Freudian psychology is essentially a male psychology framed from a male perspective.

In a similar vein, Nietzsche believed in a fundamental ordering principle of the universe, which he called the "will to power". But this is imprecise. His "will to power" is actually, a will to masculine power. In his psychology, there is no place for the feminine law. His idea of the whole universe as a battleground of contending wills and the fight for supremacy visible in every manifestation of life, is preeminently the masculine side of being. Nietzsche failed to recognize the feminine side as a valid logical reality. For ultimately, 


\section{Stephen Jarosek}

the will to power must contend with the will for continuity. The will for more of the same acts in direct contradiction to the will for change.

Of course, the dominance of men's perspectives in psychology and science has nothing to do with the oppression of women by men, and everything to do with women's disinterest in analytical pursuits. That women are not adequately accounted for in the exploration of perspectives has everything to do with women being content to leave the exploration of the unknown to men.

\subsection{Woman's secret}

From Nietzsche (Thus spoke Zarathustra), "On little old and young women":

"Then the little old woman answered me: 'Many fine things has Zarathustra said, especially for those who are young enough for them. It is strange: Zarathustra knows women little, and yet he is right about them. Is this because nothing is impossible with woman? And now, as a token of gratitude, accept a little truth. After all, I am old enough for it. Wrap it up and hold your hand over its mouth: else it will cry overloudly, this little truth."

"Then I said: "Woman, give me your little truth."

And thus spoke the little old woman:

"'You are going to women? Do not forget the whip!'”

Thus spoke Zarathustra. (Nietzsche 1954: 67)

\subsection{The provider}

An important distinction between the sexuality of men and that of women is that men desire, women long to be desired. Women do not find men attractive, so much as they find themselves attractive, within the contexts provided by successful, powerful men. That's why women use cosmetics and men do not. That's why women dress to lure, while men dress to work. Popular women at the top of the food chain prefer rich men, successful men, assertive men. Less demanding women will be content with men who are reliable, "safe" providers, who are "financially secure". Some of the men that women choose will happen to be ugly, with all the charisma of a bag of cement. Some of them will happen to be handsome, with the ability to charm birds out of trees. Some of these men will happen to be geriatrics (but rich). 
Some of them might even appear to have nothing going for them whatsoever. But the one thing that all these men have in common is that they conform to women's priorities to be provided for, to be desired.

A good provider is motivated and passionate. He desires, and he desires to win. A good provider is a successful provider. Men's lives are prescribed within the context of success and their provider role both by women and by men.

A woman is unlikely to pay for sex because being desired is central to her sexuality. A woman paying for sex does not make sense because it is an affirmation that she is not desirable. Being desired is the source of her arousal. A woman paying for sex stands in direct contradiction to the feminine desirability that demands payment. It cannot be any other way. Being paid for sex is the only monetary transaction that is capable of arousing a woman, whether or not she is a gold-digger, for there can be no stronger message that a man finds her attractive. And feeling sexy, vulnerable and attractive is a woman's thrill.

Which pretty well casts Man's role as provider in stone. Being a provider is as integral to manhood as having testicles. It is the unspoken "given" that defines Man's purpose. If, at one level, women's choices can appear to be arbitrary or indiscriminate, at another level they are very specific. If a man does not, in some way, conform to the promise of his destiny as provider, he does not get air-time.

(For the sake of simplicity, we confine our discussion here to Western cultures characterized by dominant materialism - where we will find that sexism and materialism go hand-in-hand. On the other hand, men's and women's motivations can become considerably more varied in more urbane societies characterized by respect for historical tradition, such as we might expect in some European countries, for example - but further discussion is beyond the scope of this article).

Man's provider role generates the variety - the "types" of men from which women choose, the types of men that become the cultural norms.

Because women can never understand men, the provider criterion provides a ready-reckoner that enables women to identify men who are "normal" and "reliable". Ultimately, a good provider can be assumed to be reasonably "well-behaved", because his livelihood will depend on it. 


\section{Stephen Jarosek}

The priority of men is success. Success in what a man does, defines his identity. It is a measure of his ability to take on whatever the unknown dishes out. It defines his character. But success, on its own, provides no guarantee of a woman's love. It must be success that is immediately tangible and recognizable. Artists and poets, successful as they often are in apprehending the unknown and bringing its secrets to light, fair much better with women once they have been identified as conspicuous successes - or even better, once they become celebrities.

Conspicuous success is a real crowd-pleaser, and irrespective of whether a man is a corporate executive, published author, criminal thug or just a humble leader of a pack, there will be no shortage of women willing to submit themselves to his charms.

\subsection{The provided for}

Woman's priority of sustaining the known implies the need for safety, and it prioritizes security. But it must also contend with its opposites and its excesses. With logic being what it is, security is one half of Woman's duality, where the other half is vulnerability. Thus the longing to be desired must invariably accompany the longing to be violated. Where a man might be more inclined to get his adrenaline rush jumping out of an aircraft with a parachute, a woman might be more inclined to get hers from putting herself in sexually risky situations - the thrill of feeling vulnerable and attractive at the same time. This sheds light on the rape fantasies of many women. It is also consistent with the observation that some women delight in their part in the sex industry (contrary to popular feminist dogma). In her narcissistic self-indulgence in her own beauty a woman sustains the known, and her thrill of being violated portends its destruction.

Dasein tells us that there is something that women "like" about their condition. There is something they "like" about dressing to be undressed. There is something they "like" about falling out of a backless, strapless, dress slit up to the hips to reveal long legs and a plunging neckline to emphasize full breasts. There is something they "like" about being beautiful and vulnerable and about surrendering to the thrill of the forbidden. There is something they "like" about being constrained in high-heeled shoes and concealed under make-up. There 
is something they "like" about being chained with jewelry around their necks and wrists and on their skin and about feeling like a valuable possession. By realizing the connection between mind and body, we know that there is something that women "like" about submission, being led, being taken, and being provided for. There is something that women "like" about intimacy and touch and breastfeeding their infants.

We know these things because we understand Dasein. Women dress to emphasize female vulnerability. Women dress to be undressed.

Feminists can often provide interesting perspectives on the longing to be violated. Published author and feminist Catharine MacKinnon observes:

I think that sexual desire in women, at least in this culture, is socially constructed as that by which we come to want our own self-annihilation. That is, our subordination is eroticized in and as female; in fact, we get off on it to a degree, if nowhere near as much as men do. This is our stake in this system that is not in our interest, our stake in this system that is killing us. (MacKinnon 1987: 54)

Alysabeth's feminist stripper site ${ }^{6}$ sheds further light on the experiences of women - though consistent with what we've already discussed, it is difficult to extract the deeper truths, and we still need to resort to inference. Nonetheless, we can obtain a sense of her experiences, for example, where she writes, "It's scary the first time you take off all of your clothes in front of a roomful of people. I imagine it's a little like skydiving (and am absolutely unwilling to find out for sure), with the adrenaline and the exhilaration".

It is clear that Alysabeth and the other strippers that she has included on her website, all enjoy their work. Moreover, Alysabeth describes a threshold that needs to be crossed. She remembers being warned by other dancers that "this was not to be entered into lightly or unadvisedly, that I was about to change my life". She describes an entry into a new kind of world that changes her. "I crossed the line. I realized that I loved it."

This brings us to an interesting and important question. What is it that happens to a person when they make such a transition? Is there something important that is changed forever, once someone makes a

6 Alysabeth's stripper site - http://www.alysabeth.com/ - as on 27 January, 2001 


\section{Stephen Jarosek}

choice and enters a new doorway? Alysabeth tells us that, "They were right. It did change my life".

Is there something to fear in such a transformation?

Revisiting everything that we've explored on the topics of desire, choice, habit and association... has something "happened" to Alysabeth that is perhaps not as benign as our secular cultures would like to believe?

Alysabeth is obviously delighted and relieved that she had not turned into a 6-legged, 4-eyed monster, and she was unable to identify any disincentive to continue. But has she transformed into something different, on that day that she walked through the doorway into the forbidden?

I am reminded of a young woman who used to work as a prostitute. She had explained to me that she had reached a point during her brief "career" where the only times she climaxed were when clients were particularly abusive and vulgar. Her feminine beauty and vulnerability juxtaposed against obese, sweaty, and gross masculine ugliness what manner of Dasein is this? What starker example of violation, in its most primal essence, can I provide? What state of being does her desire to be allude to? The most civilized and well-presented among her clients left her cold. To most men this would seem inconceivable how could a man possibly be aroused by the sight of an ugly woman? And in this, we see that men and women really do inhabit vastly different worlds. Does it really make sense to infer that an attractive woman, who can have anyone she desires, can be aroused by ugly, vulgar men - the uglier the better? Yes, it can. This is explicable by understanding female sexuality from the perspective of the longing to be violated. Violation taken to its limits exposes a woman to a strange, surreal condition that disengages her from the real world. Vulnerable and exposed, she experiences life at the limits. The very outrage of a beautiful woman choosing and being violated by a vulgar boor has its own kind of thrill. The risk that her parents might find out, what her friends might think, all these things come together in a context that heightens the surreal elements of her experience. Such thrills are not always without consequence, for the self-loathing, the neuroses and the mood-swings often characteristic of some of these women is logically consistent with the contexts that they have chosen to enter into. 
We know that women who have been sexually abused, or women who have experienced the sex industry, are often "drawn" to further violation long after they have left their experience behind. A secret longing often compels them to covertly indulge in more of the same even though they might be able to recognize it as violation and even though they might want out. Where did this come from?

We might now better understand Alysabeth, when she describes her experience in terms of exhilaration not unlike that which might be had skydiving. The expression of female sexuality, like skydiving, is accompanied with inherent risks that add to the thrill. Entered into without caution, there exists the possibility of real and long-term psychical harm. More importantly, her desires will change in order to accommodate her choices, and it is in this that the greatest psychical harm is done. As she attests on her website, Alysabeth has come to enjoy all the other contexts that accompany her dancing — the glamour, the camaraderie, the lit-up stage, the dark corners, the smoky atmosphere - she has immersed herself into her contexts and all this is a manifestation of her Dasein, her desire to be. Alysabeth likes her Umwelt. It will continue to draw her in. Should this be such a problem?

For how many more years can a stripper continue dancing? Perhaps the man she is currently with loves her for what she is. Then again, maybe his life contexts, as a man who dates women who get paid on these terms preclude her from his life's agenda. Or maybe she doesn't need a man. Does it matter? Does she care? Dasein. The contexts she revels in today won't always be so kind to her in the future:

The choice becomes the association of habits becomes the desire becomes the need.

Can a sex-worker believe in a life hereafter? If so, how might she think that the contexts she immerses herself in today will manifest themselves in her hereafter? Whether or not she believes in any such thing, perhaps we need to be concerned. How do the options we permit today, impact on what our cultures become tomorrow? What is the connection between the debauchery of today and the criminality of tomorrow? If not criminality - then how might the debauchery of today relate to the prudishness, the uptightness and the hangups that might manifest themselves anew to extricate this virus from the 
cultural body? How might the power of an authoritarian tyrant tomorrow relate to today's permissiveness that corrodes the will to stand up for one's rights? More generally - how is the present semiotically and logically connected with the future? With what sort of cultural dynamics is the longing to be violated logically consistent?

Prior to modern feminism, it has commonly been accepted that many "traditional" women wanted to be "dominated". But this wanting to be dominated suggests a comparatively innocent, innocuous desire assumed by genetic determinists to be genetically programmed into women to select for successful, virile men. And to further confuse matters, feminists reacting to what they've perceived as a patriarchal conspiracy, have simplistically blamed "traditional" men for indoctrinating women into submissiveness. Both interpretations are wrong and a more sophisticated analysis is required.

Domination was something that characterized successful men. Successful men (and by implication, dominating men) were respected by both men and women alike. It was a cultural "tradition" — an expectation by men and women - that a woman should be financially dependent upon a successful provider. A successful man (and therefore a dominating one) was sought out by an image-conscious woman. From a semiotic perspective, a woman's desire for a successful man was a desire for a dominating one and therefore, an act of complicity in which she expected to be dominated.

A woman's desire to be dominated is not part of a brain module designed to select for superior men but rather, her desire to be dominated manifests in her sexuality as the longing to be violated in a more materialistic form. At its core is the urge to submit to and be consumed by forces beyond one's control, to be swept away to become part of something new.

So let's distill this wanting to be dominated to its essence, and call it for what it really is - the longing to be violated. And in this context, we realize that it does not always select for superior men.

Of course, most women do not, in reality, want to be violated. And among any that might, if they could understand what is meant by "violation", they would probably deny it. Most often, the longing to be violated remains just that - a longing hopefully confined to the realm of fantasy, and not to be actualized in real life. But it is a longing that establishes predispositions to the types of choices that are made. The risk of violation constitutes part of the logic by which a woman 
experiences her feminine beauty. To define what is beautiful is to define what is not beautiful. If "innocence" is the essence of feminine beauty, then the destruction of innocence is violation.

The primary responsibility of innocence is to sustain the known for ultimately, the desire to be and to continue being is the most elemental desire. Only the experienced might seek to do away with themselves, to try to find a way out of being. Sustaining the known is accompanied with the risk of its destruction. And accompanying that risk is a thrill, not unlike jumping out of an aircraft with a parachute. Femininity and feeling sexy, beautiful and vulnerable accompanies as part of its logic, an awareness of the risk of violation that every woman must, subconsciously at least, sense. This awareness comes from within. The fear that is often associated with femininity is neither neurotic, nor can it be blamed entirely on men. A woman's fearfulness is a part of the thrill by which the known interacts with the unknown. The interaction carries with it real risks, and her fear is justified. Thus, while men are often violators, such aggression does not magically appear in a vacuum, but constitutes a part of the shared cultural logic that women also indulge in.

The longing to be violated sheds light on the choices that some women make. For surely, does not the longing to be violated require... a violator?

A woman's longing to be violated requires a formidable, dynamic force if it is to be awakened. Neither chivalrous men who are wellbehaved, nor sensitive dishwashers too afraid to try, will ever rouse the beast that sleeps within her. No woman can long to be violated by just anyone. The dumbing down of men that is required to accommodate the demands of political correctness is the last thing that women really long for. Sensitive dishwashers have no part to play in women's rape fantasies - though as predictable, safe providers who make minimal demands, they can make excellent marriage partners;

The longing to be violated, in the subtle context of the logics by which beauty and innocence are defined, is a woman's secret that she keeps not only from men and other women, but also from herself. To conceal her desires, she will practice deceit and self-deceit. Sustaining the known is her responsibility, and she must be seen to uphold standards. Yet her exposure and her vulnerability, the tension between her beauty and the danger that surrounds her, reflected in the clothes she wears, is her private thrill. And the secrecy is itself a part of the 
thrill, because it is a reminder of her responsibility as mother and sustainer of the known. There can be no greater forbidden than the desire that must be kept secret, no greater thrill than to submit to the longing for forbidden fruit.

From our foregoing semiotic analysis coupled with wider observation, it might be inferred that for many women, the longing to be violated is not realized until it is "awakened" in them through circumstance (for example, through marriage or introduction to sex work). But once awakened, a woman must keep her secret well hidden, for she will know that most women will not only not understand, but they will actively deny this side of their nature that is hidden from them. Quite apart from the fact that she won't even know how to put it into words, for that which is secret is that which fails to make it into language.

And so there exists a powerful conspiracy of silence among women where a host of contradictory interpretations, from wanton debauchery to prudish conservatism, has everyone - men and women - trying to guess what women really want. But the one real truth - Woman's secret longing to be violated - remains obscured by all the chatter and noise.

\subsection{The longing to be violated and the power of veto}

Female is the gender predisposed to experiencing first-hand the consequences of violation. Therefore Woman is predisposed to the realization, at least at some primal level, that her choices have consequences. Woman is predisposed, at one level, to being able to control her sex drive, because she perceives her choice to be between being accepted into the future or cast into oblivion. And control of her libido is logically consistent with the fear of losing control. This is why Woman's power is the power of veto. She needs to be sold. She needs to be swayed, wooed and convinced that her choice is the right one. If, at one level, Woman is predisposed to making a moral decision or an immoral one, at another level, she is not predisposed to analyzing that decision. She is not predisposed to understanding her options, because reality is far too complex. The cultural known simplifies reality. Making assumptions about the way the world is is the only way to cope with all this complexity. This is why women are the assumers of the cultural known. This is why they think in "henids". 
And so Woman is faced with two important dimensions to her existence that are often contradictory:

(1) An intimate connection with the consequences of violation;

(2) The cultural known.

When culture becomes immoral, Woman turns to peer pressure to define how she is to behave. Peer pressure can blind her to the consequences of violation. If, from one perspective, violation can be perceived to cast her into oblivion, from another perspective, not being accepted by her peers can be perceived with an even greater urgency. The consequences of sexual "freedom" - within the context of its inextricable connection with peer pressure - can be disastrous. Within this logical realm, women's choices can seem utterly incomprehensible to men.

By contrast, men are removed from the immediate consequences of violation. Men are more concerned with the immediacy of survival and utilizing the options that are presented to them, whether or not those options conform to the cultural norms. It is women that enjoy the power of veto - they set the limits of sexual morality. And it is men that operate within those bounds, testing the limits and learning what they can get away with.

\subsection{The writings of Anaïs Nin}

In her Diary, Nin wrote, "to be violated is perhaps a need in a woman, a secret erotic need". Her stories focus on man as possessor and woman as possessed, of man as violator and woman as violated. Whilst these are themes common to "mainstream" pornography, what makes Nin's work particularly important is that they are presented from a woman's perspective, and in an entirely different language. More importantly - and in contrast to pornography for mainstream consumption - they shed light on the motivations of women.

Conventional pornography (assumedly written from man's perspective) presents sexuality largely in adolescent terms. We imagine that a typical consumer of pornography, today, probably spent the high points of his childhood pulling wings off flies. Blind to the more formidable dynamics of sexuality - for example, that which exists between the sanctioned and the forbidden, the known and the unknown - the sex drive is reduced to nothing more than an itch, 
with relief provided only in orgasm. Similarly, it is common to portray women as being devoid of any sex drive - the truth behind this overgeneralization being that women can be so materialistic that they rarely get to discover their "dark" sides. Such women typically possess a kind of sterile innocence, with their lives being dominated by an agenda that finds its greatest fulfillment in being provided for. And herein lies the unity of culturally shared logic. Bored women and desperate men are an inevitable outcome of the mutually consistent logic that must accompany today's sexual "freedom" (obsession). We have the paradox of women-as-sexuality leading non-sexual lives. Their sexualities are every bit as consuming as men's, yet it is men, consumed by their itch, who must pay for sex.

But Nin's writings provide a more authentic depiction of sexuality. Not only do they make sense in terms of the mind-body unity (men's and women's bodies as tools) that I introduced in my paper (2001), but they capture the essence of that interface between the known and the unknown, between the fear and danger and the tension that lie at the core of primal sexuality. For example, in "The woman on the dunes", Nin (1979) has the heroin of the story relate to her lover, an account of sex with an anonymous stranger during an execution:

Her eyes remained fixed on the man who was mounting the scaffold, and with each beat of her heart the penis gained headway. It had traversed the skirt and parted the slit in her panties. How warm and firm and hard it was against her flesh. The condemned man stood on the scaffold now and the noose was put around his neck. The pain of watching him was so great that it made this touch of flesh a relief, a human, warm, consoling thing. It seemed to her then that this penis quivering between her buttocks was something wonderful to hold on to, life, life to hold while death was passing...

Without saying a word, the Russian bowed his head in the noose. Her body trembled. The penis advanced between the soft folds of her buttocks, pushed its way inexorably into her flesh.

She was palpitating with fear, and it was like the palpitation of desire. As the condemned man was flung into space and death, the penis gave a great leap inside of her, gushing out its warm life.

The crowd crushed the man against her. She almost ceased breathing, and as her fear became pleasure, wild pleasure at feeling life while a man was dying, she fainted. (Nin 1979: 18-19)

In "A model", Nin (1979) provides an abundance of insights. She eloquently explores that boundary between the sanctioned known and 
the forbidden unknown - and provides interesting perspectives on how intruding strangers can penetrate that boundary and into women's lives.

But the overwhelming theme emerging from Nin's writings is her belief that a woman can only obtain proper sexual fulfillment with a man who overpowers her. Accordingly, a woman might resist a man's advances. She might even scream and hit out, in her efforts to escape. But Nin's typical romantic adventure has the woman being overpowered - and along the way, she discovers her secret that she actually enjoyed the experience.

A woman does not seek out experiences, because she does not have to. Rather, she has them happen to her, and in this way, she discovers what she desires. That is her role as sustainer of the known. A woman will not seek out to be violated, but in the right contexts, can actually enjoy it when it happens to her. Exploring the unknown (seeking out violation) is not her territory. To men who habituate working and competing for anything of value, this sounds unbelievably easy... and indeed, it is. But as discussed above, such freedoms are also chains, for the habit of being provided for is logically consistent with the habit of dependency. In a very real sense, it is because women have it so easy that they have it so hard. And in these contexts, we can begin to make inferences about women's logic, to help us understand all the complexities of women's behavior. We can now begin to understand the contexts in which a woman might secretly enjoy being raped.

Nin (1979) begins "Hilda and Rango":

Hilda was a beautiful Parisian model who fell deeply in love with an American writer, whose work was so violent and sensual that it attracted women to him immediately. (Nin 1979: 101)

But her writer lover was not the virile stud his writings seemed to suggest:

They lived together for several years, deeply attached to each other. She became accustomed to his sexual rhythm. He lay back waiting and enjoying himself. She learned to be active, bold, but she suffered, because she was by nature extraordinarily feminine. Deep down she had the belief that woman could easily control her desire, but that man could not, that it was even harmful for him to try. She felt that woman was meant to respond to man's desire. She had always dreamed of having a man who would force her will, rule her sexually, lead. (Nin 1979: 102) 


\section{Stephen Jarosek}

Then one night at a party, Hilda met a Mexican painter (Rango), who was almost always drunk:

But the sight of her gave him a profound shock. He pulled himself up from his faltering, tottering posture and faced her as if he were a big lion facing a tamer. Something about her made him stand still and try to become sober again, to rise from the fog and fumes in which he lived continuously. Something about her face made him stand ashamed of his unkempt clothes, the paint under his nails, the uncombed black hair. She, on the other hand, was struck by this image of a demon, the demon she had imagined to exist behind the work of the American writer.

He was huge, restless, destructive and loved no one, was attached to nothing, a tramp and an adventurer. (Nin 1979: 102-103)

At one stage in her encounter with Rango, Hilda transgressed a sacred taboo by initiating sex but was harshly rebuffed with the charge that she "made the gesture of a whore". Hilda regarded the passive, gentle, unmanly behavior of her previous, long-time lover (the writer) as the source of her problem:

A deep shame, a sense of great injury overwhelmed her. The woman in her that had suffered from being forced to act as she did with other lover, the woman who had been made to betray her real [feminine] nature so often that it had become a habit, this woman wept now, uncontrollably [...] (Nin 1979: 105)

and

She dropped exhausted on her bed and fell asleep weeping, not only for the loss of Rango but for the loss of that part of herself she had deformed, changed for the love of a man. (Nin 1979: 105-106)

Hilda regarded her proactive, initiating nature as a perversion of her true, feminine form. She felt that Rango was withholding sex as a consequence. Writes Nin:

Had he understood that it was involuntary, not truly in her? (Nin 1979: 107)

Hilda had numerous encounters with Rango, but without having had their relationship consummated: 
Over and over again she lay passive, showing no desire, no impatience, which exacerbated her sensibilities. It was as if she had taken new drugs that made the entire body more alive to caresses, to a touch, to the very air. She felt her dress on her skin like a hand. It seemed to her that everything was touching her like a hand, teasing her breasts, her thighs continuously. She had discovered a new realm, a realm of suspense and watchfulness, of erotic wakefulness such as she had never known. (Nin 1979: 107-108)

And after Hilda rediscovered her true, feminine nature, she was rewarded:

One day when she was walking with him, she lost the heel of one shoe. He had to carry her. That night he took her, in the candlelight. He was like a demon crouching over her, his hair wild, his charcoal-black eyes burning into hers, his strong penis pounding into her, into the woman whose submission he first demanded, submission to his desire, his hour. (Nin 1979: 108)

In romance, the man is obliged to initiate, to lead and ultimately to take, with the woman following in submission. This is an expectation not only of men but also of women. In rape, the successful rapist takes. He demands submission and gets it. And if the contexts are right - that is, if the rapist is "sexy" (successful, confident) - there can be, for many a woman, perhaps no greater thrill.

In Hinz (1975: 45), Nin was asked the question, "Do you still believe that "to be violated is perhaps a need in woman, a secret erotic need," as you wrote in Diary II?" Nin replied:

This may be part of the primitive programming of woman, which psychology has analyzed in various ways: one, as a test of the man's strength; the other as a way of eluding the burden of sexual guilt. If someone with a will stronger than hers "rapes" a woman, she is not responsible for the sexual act. These dreams may disappear when woman is freed of guilt for her sexual desires. Hinz (1975: 45)

\subsection{Feminine sexual perversion}

Predictably, within the context of today's pop psychology, Nin's perspective is often interpreted as indicative of some sort of pathology. Her incestuous relationship with her father has often been sited as the source of her problems with sexuality. Conceivably, this relationship may have set her on the path that she had taken. But was 
the manner in which she adapted to her relationship with her father, "wrong'? That is to say, was hers an "incorrect", "perverted" interpretation of reality? Or was her interpretation, in fact, the essence of feminine sexuality precipitated by a dangerous unknown, as provided by the erratic, irresponsible behavior of her father?

Thus we come to a very important point about female sexuality. For women, it is "discovered". Sex is an essentially passive activity that happens to them. At its core, at the very essence of female sexuality is the longing to be violated. Violation is an essential feature of the sex act, and provides the basis for intimacy in a loving relationship - there are many women who do not want to be violated by "just" anyone. And with all the implications that are possible with the longing to be violated, many women do not get to "discover" their sexuality. For all their sexual activity, many women can remain sexless and barren, consumed solely by the priority to be materially provided for.

Thus we can infer that Anaïs Nin's sexuality was not a perversion. That is to say, it was not a diversion away from femininity but rather, a primal expression of it. Her sexuality was an essential manifestation of the feminine longing to be violated. And while her writings reflect a sensuality and honesty that might be healthier than the sterile conformity of many of her more materialistic sisters, we should be mindful of the implications of being violated. For how does violation impact on a person's psyche? How does female sexuality impact on cultural evolution? For does not sexual "freedom" imply the emergence of violators? Is there a healthier way in which female and male sexuality might be expressed, beyond the extremes provided by yesterday's conservatism and today's liberalism?

\subsection{The relationship between promiscuity and criminality}

We are now in a better position to consider what might be wrong with sexual "freedom".

Women's priority to sustain the known implies assuming rather than understanding. The simple truth is that women do not understand women. They are even less likely to understand men. Assuming bears no relationship to understanding. In fact, their failure to understand men provides the key to what they experience as an exciting fear of the 
dangerous, unpredictable unknown that belongs to men. Their failure to understand men is what can make the unknown so exciting to them (beyond the banal pretensions of modern liberalism). And it would seem to suggest a connection between promiscuity and the types of men that are chosen. The gender enjoying the culturally sanctioned privilege of being provided for is the gender least likely to understand the choices that are being made. For women, sexual freedom might be wonderful and empowering, but in terms of evolution, it is problematic because the choices they make will be confined to a particular spectrum of male stereotypes. Moreover, women learn what men are supposed to be like from the types of men to whom they give air time - which in the modern climate of liberal social values, happens to be the types of men that are more likely to intrude without sensitivity to cues. The type of man most likely to initiate, in the modern context of sexual "freedom", is the type least likely to respect personal space. The type of man most likely to initiate is the type most likely to get in women's faces and ipso facto, the law of averages suggests that he will be selected. Such a man will understand only the law that guarantees his success with women: No initiate, no sex.

Bad-boys get in women's faces. In a sexually permissive society, women give them air-time. And so it is clear that, from the perspective of the numbers game, bad-boys will get lucky. "No initiate no pussy" is the simple, universal and natural law that states that if you're not in it, you can't win it. As Sanchez (aka Greg Entner of Bangbus Videos ${ }^{7}$ fame) illuminates on his website, in his list of FAQs:

Q: How are you guys able to pick up girls off the street and fuck them?

A: Because we ask them. ${ }^{8}$

Sexual "freedom" invariably implies sexual randomness and the lowering of standards. It appeals to the fears of women (especially fear of solitude) and the baser instincts of men.

Weininger (1906) wrote on the implications of female promiscuity taken to its limits. He explored the connection between prostitution

\footnotetext{
7 I am not going to promote their website - I will, however, refer to it as a part of my analysis.

8 Irrespective of the extent to which "reality porn" is staged (choreographed), this dynamic is consistent with the reality of modern youth culture as suggested in Ariel Levy's book, Female Chauvinist Pigs.
} 
and criminality (he used the word "prostitute" in a general sense, to identify women that are promiscuous or of "loose" morals). The following excerpt summarizes his perspective:

Very deep-seated differences are linked with what I have been describing. The mother-woman craves for respectability in the man, not because she grasps its value as an idea, but because it is the supporter of the life of the world. She herself works, and is not idle like the prostitute; she is filled with care for the future, and so requires from the man a corresponding practical responsibility, and will not seduce him to pleasure. The prostitute, on the other hand, is most attracted by a careless, idle, dissipated man. A man that has lost self- restraint repels the mother-woman, is attractive to the prostitute. There are women who are dissatisfied with a son that is idle at school; there are others who encourage him. The diligent boy pleases the mother-woman, the idle and careless boy wins approval from the prostitute type. This distinction reaches high up amongst the respectable classes of society, but a salient example of it is seen in the fact that the "bullies" loved by women of the streets are usually criminals. The souteneur is always a criminal, a thief, a fraudulent person, or sometimes even a murderer.

I am almost on the point of saying that, however little woman is to be regarded as immoral (she is only non-moral), prostitution stands in some deep relation with crime, whilst motherhood is equally bound with the opposite tendency. We must avoid regarding the prostitute as the female analogue of the criminal; women, as I have already pointed out, are not criminals; they are too low in the moral scale for that designation. None the less, there is a constant connection between the prostitute type and crime. The great courtesan is comparable with that great criminal, the conqueror, and readily enters into actual relations with him; the petty courtesan entertains the thief and the pickpocket. The mother type is in fact the guardian of the life of the world, the prostitute type is its enemy. But just as the mother is in harmony, not with the soul but with the body, so the prostitute is no diabolic destroyer of the idea, but only a corrupter of empirical phenomena. Physical life and physical death, both of which are in intimate connection with the sexual act, are displayed by the woman in her two capacities of mother and prostitute. (Weininger1906: 233-234)

Another way of interpreting this problem with sexual freedom is the relationship between innocence and power.

When a man feels the urge to violate, what is it that he wants to take?

Innocence.

When a woman longs to be violated, what is it that she longs to submit herself to?

Power. 
In a sexually permissive society, intruding initiators indulge themselves in the fantasy of innocence violated, and submitting exhibitionists indulge themselves in the fantasy of power violating. A culture so predisposed entertains the false, exaggerated illusions of women as virtuous, sweet innocents and of men as immoral, brutish thugs. If taken to its logical conclusion, unrestrained permissiveness turns women into imbeciles and men into criminals. And in keeping with the dualistic nature of logic, women become harder, more cynical and bored, while men become softer, more docile and desperate. The dynamics between innocence and power - whether exaggerated or subdued, real or imagined, sanctioned or denied - lie at the heart of every sex act and for this reason, there is no such thing as trivial sex, no such thing as sex without consequence.

\subsection{The perspectives of other established works}

We have covered a lot of ground from a semiotic perspective. Before closing off our analysis, let us briefly examine how these ideas relate to the work of other more academically conventional writers, such as Seymour Fisher, William Masters \& Virginia Johnson and Alfred Kinsey.

Fisher (1973: 53) suggests something of the mind-body unity (the relevance of the body-as-tool in shaping personality) when he refers to "body-image parameters". He refers to a sizeable scientific literature (Fisher, Cleveland 1968; Fisher 1970; Shontz 1969) demonstrating that body attitudes do affect behaviour:

Clear evidence has accumulated that persons vary in the ways in which they integrate and interpret their body experiences and that, in turn, these adaptations affect their personality style.

Expressing these ideas in Academese in this way denies the reader the sort of clarity that would otherwise be made possible from a semiotic perspective. However, within the context of the fundamental semiotic principles that were introduced at the start of our paper, we can nonetheless confirm that we share common ground with Fisher's analysis. Referring to writers such as Fried (1960) and Masters and Johnson (1966), Fisher notes the importance of the involvement of the 
whole body in sexual experience - for example, breathing perspiration, vocalization, as well as changes in sensory acuity, throbbing of body parts, temperature changes, muscle tensions, etc. He observes that:

[...] A number of writers converge in emphasizing that fear of intrusive body penetration and of losing body boundaries is a prime cause of disturbed response to sexual stimulation. They suggest, each with his own phraseology, that a woman's conviction that her body is too "open", insufficiently protected, and incapable of resisting invasion can make her interpret sexual sensory experiences, with their accompanying expectations of being entered by the penis, as destructive.... It is the threat to the fundamental boundary that is confronted in sexual interaction that is said to be so disturbing to many women. (Fisher 1973: 53)

In other words, fear plays some important, inextricable part in Woman's experience of sexuality.

Fisher (1973) discusses the notion that the excitement that builds up during sexual arousal is often associated with a woman's sense that she is losing control. From our semiotic perspective, this continues to fit with Woman's logical world. The sustainer of the known, consolidating her known world "in here", is likely to fear the loss of control that is implied in submission and abandonment. And indeed, Fisher does make the connection between fear and loss of control, citing psychoanalytic observers who have reported from their patients that fear of loss of control and madness is associated with orgiastic arousal. Fisher observes:

Although the foreboding implications of "losing control" have been pointed to by some, others (for example, Fried 1960) consider that the sensation of potential loss of control is for many women a piquant enrichment of the sexual arousal experience. It is the opening of self to a sense of undisciplined excitement that presumably makes sexual interaction especially enjoyable. Paradoxically, some (Feldman 1951) even suggest that fear which is set off by sexual arousal may itself further energize, rather than inhibit, the arousal process. A variety of examples are cited by Feldman of instances in which orgasm seemed to be produced by fear and anticipation of danger. It is explicitly assumed that fear can be "sexually exciting". (Fisher 1973: 59)

Fisher includes excerpts from interviews he's had with women on their descriptions of their experiences of sexual arousal (Fisher 1973: 203-209). As we read through these excerpts, we might be reminded 
of Otto Weininger's thesis that Woman is sexuality (contrasting with Weininger's notion that Man's sexuality is functionally separate to his identity). On the sorts of fantasies that women had during intercourse, Fisher reported that more than 75 percent of the women indicated that they had at least one fantasy or image that recurred occasionally (but not infrequently). Of these, "about 40 percent involved scenes in which the woman was having a sexual contact or interchange with someone other than her husband". And of these, "more than half of the instances revolved about themes in which the woman perceived herself as being raped, sexually humiliated, or somehow sexually wicked". These included fantasies relating to bondage, brutal rape and humiliation, with masochistic and exhibitionistic elements strongly represented. Thus we observe, as a rough, back-of-hand guesstimate, that at least about $15 \%$ of Fisher's respondents admitted to having fantasies of rape, humiliation and violation.

Let's follow this through in another part of the book (Fisher 1973: 89), where Fisher refers to a study by Barclay and Harber (1965). Here, a male experimenter frustrated and angered male and female subjects, and then analyzed their reactions to test for the role of anger in sexual imagery. It was found that the experimentally induced anger resulted in increased sexual imagery for males and females. Importantly, as Barclay and Harber (1965) observe, "Women responded to aggressive arousal by a male with an increase in sexual imagery, not a reduction of it [...]. Thus, from the female's point of view, aggression is an important aspect of a male's sexual appeal".

The researchers were able to detect that anger increased the sexual imagery in both men and women. However, were the researchers able to discern the content of their respective imageries? From the geneticdeterminist perspective, we might expect that the reactions of men and women were "equivalent" in logic and content. However, from a semiotic perspective, we would expect the male and female reactions to be complementary. That is, both sexes will react with an increase in sexual imagery, but women will do so with a feminine logic (for example, from the perspective of being desired or being violated) that bears no resemblance to the men's (desiring/violating).

Elaborating on the implications of anger in arousing women sexually, Fisher refers to further studies exploring a variety of themes (e.g., death material was said by female subjects to be sexually stimulating). He infers that "a rather esoteric range of stimuli has 


\section{Stephen Jarosek}

psychosexual meaning to women". In at least two studies, Fisher notes, "an extreme group of women has been found to be more sexually aroused by 'psychosexual' stimuli than any of the male subjects".

Fisher (1973: 393-394) raises an extremely important point with respect to the work of Kinsey et al. (1953) and Masters and Johnson (1966), who limit their analyses to women's experiences of orgasm. Fisher alludes to the need to address female sexuality from a more contextual perspective that embraces the entire experience of sex. It is understandable that writers grounded in what amounts to a Male Psychology, will tend to write about female sexuality from a male perspective that attributes greatest meaning to the build-up and release in orgasm. If many of Fisher's subjects recount experiencing orgasm, what do they really mean? Can a self-reported orgasm by a woman resemble in any way a man's orgasm? Does it make sense at all to discuss female sexuality in these terms? Is it more true to say that gender roles exist because of the fundamental subjectivity of existence that can never breach the confines of the mind-body unity? That is, are male and female experiences destined to remain forever unfathomable from the perspective of the opposite sex?

How do those of us who do not inhabit female bodies plumb these inner depths of women's sexual experiences? If Weininger is correct in his view that Woman is sexuality, is this also what we might infer from Fisher's observation of the breadth of stimuli to which women attribute psychosexual meaning?

\subsection{Conclusion}

Throughout this paper, we have provided a theoretical basis for understanding the differences in the psychologies of men and women:

(1) We have applied Peirce's Great "Law of Association of Habits" to understand that gender roles are habitual and associative - and thus, inextricably related to choice. Men and women make choices from their ecologies (cultures) and in their complicity, choose the gender roles they habituate. These gender-specific habits become the cultural norms that are the expectations of how we should be; 
(2) From Heidegger's Dasein, we know that men and women "like" the roles to which they have been assigned, and we need no further proof than their complicity. Dasein - the desire to be ensures every person's complicity and thus, their culture's survival across the generations;

(3) Men and women inhabit different logical realms (the known versus the unknown) that can be best understood by regarding men's and women's bodies as tools, designed specifically to deal with their specialized realms.

With this theoretical foundation, we have been able to infer how the opposite sex experiences their worlds. But the implications are far wider than this humble conclusion would seem to suggest. To begin with, we are applying Peirce's general theories of cognition (for example, in the field of biosemiotics), that might be more broadly extended beyond the opposite sex, to infer how other organisms might interpret their worlds. And in doing so, we are opening up a Pandora's box of interpretations. Where Copernicus showed us that our planet was not the center of the universe, semiotics would show us that the human condition is not that special, sanctified, purified and homogenized center of existence that we have deluded ourselves into believing. We are going to have to climb down from our pedestals, for we are truly one with the beasts.

Indeed, if we were to probe deeper, we might find that the whole basis upon which we judge character and human worth is more than suspect. For if one half of the population is judged in terms of courage and the other half in terms of the opposite to courage (which is innocence), does this not throw into disrepute everything that we have come to know about the human condition? For how has it come to pass, that a man with a woman's personality should be deemed a loser, and a woman with a man's personality should be deemed repulsive? Can't we just as easily deem all men to be repulsive, for without women, would not the vast majority of men have dubious toilet manners, and be without any motive for politeness and diplomacy? And can't we just as easily deem all women to be losers, for without men, would not the vast majority of women be scavenging from bins and sleeping on pavements in dark alley-ways? Whilst the vast majority of destitutes are men, the vast majority of women are exempt from this status only because it is culturally sanctioned that they be 
provided for - a woman need only marry a politician, lawyer or doctor to be afforded the same high social status as that of her partner. Yet, a man with the same character traits as a kept woman would be treated only with contempt.

In our semiotic exploration of the psychological differences between men and women, what should become clear is the subjective nature of existence. Our bodies provide the interface between our thoughts and the outside world, and there is no way of circumventing this subjectivity - as surely as there is no way of circumventing the physical laws of motion or the law of conservation of energy. We remain trapped in our bodies. Inasmuch as this article represents about as good a job as can possibly be done in inferring how women experience their worlds, there remains that chasm that can never be crossed. Human men and women must remain forever logically distinct, as a fundamental law of reality. I must become Woman, completely and absolutely, in order to truly understand her innermost thoughts. I must forget all my prior experiences and I must forget that I ever was a man, in order to truly understand the feminine condition, in all its subjectivity and vulnerability. And in this, I will lose forever, the ability to achieve what I have done in this article.

We remain aliens to each other's worlds, but forever united in our subjectivity and the law of association of habits. And in understanding this much, perhaps we might feel a closer bond of understanding with an alien, should we ever chance upon a visitation from outer space.

\section{References}

Bjorqvist, K. 1994. Sex differences in physical, verbal and indirect aggression: A review of recent research. Sex Roles: A Journal of Research 30: 177-188.

Bloom, Howard 1995. The Lucifer Principle: A Scientific Expedition into the Forces of History. New York: Atlantic Monthly Press.

- 2000. Global Brain: The Evolution of Mass Mind from the Big Bang to the 21st Century. New York: John Wiley \& Sons.

Chesler, Phyllis 2003. Woman's Inhumanity to Woman. New York: Plume Books.

Crick, Nicki R. 1995. Relational aggression: the role of intent attributions, feelings of distress, and provocation type. Development and Psychopathology 7: 313-322.

Crick, Nicki R.; Grotpeter, Jennifer K. 1995. Relational aggression, gender, and social-psychological adjustment. Child Development 66: 710-722. 
Farrell, Warren 1994. The Myth of Male Power. Sydney: Random House Australia Pty Ltd.

Fein, Ellen; Schneider, Sherrie 1995. The Rules. New York: Warner Books, Inc.

Feldman, S. S. 1951. Anxiety and orgasm. Psychoanalytic Quarterly 20: 528-549.

Fields, R. Douglas 2004. The other half of the brain. Scientific American 290(4): 27-33.

Fisher, Seymour 1973. The Female Orgasm: Psychology, Physiology, Fantasy. London: Allen Lane.

Fried, Edrita 1960. The Ego in Love and Sexuality. New York: Grune \& Stratton.

Harris, Judith 1998. The Nurture Assumption. New York: Simon \& Schuster.

Heidegger, Martin 1978. Being and Time. (Macquarrie, John; Robinson, Edward, trans.) Oxford: Basil Blackwell.

Hinz, Evelyn 1975. A Woman Speaks: The Lectures, Seminars, and Interviews of Anaïs Nin. Chicago: Swallow Press.

Jarosek, Stephen 2001. The law of association of habits. Semiotica 133(1/4): 7996.

Kinsey, A. C.; Pomeroy, W.; Martin, C.; Gebhard, P. 1953. Sexual Behaviour in the Human Female. Philadelphia: W. B. Saunders Co.

Lagerspetz, K. M.; Bjorqvist, K.; Peltonen, T. 1988. Is indirect aggression more typical of females? Gender differences in aggressiveness in 11 and 12-year old children. Aggressive Behavior 14: 403-414.

MacKinnon, Catharine 1987. Feminism Unmodified: Discourses on Life and Law. Cambridge: Harvard University Press.

McCrone, John 1993. The Myth of Irrationality - the Science of the Mind from Plato to Star Trek. London: Macmillan.

Masters, William H.; Johnson, Virginia E. 1966. Human Sexual Response. Boston: Little, Brown, and Co.

Nietzsche, Friedrich 1954. Thus Spoke Zarathustra. (Kaufmann, Walter, trans.) New York: The Viking Press.

Nin, Anaïs 1979. Little birds. New York: Harcourt Brace Jovanovich.

Peirce, Charles S. 1966. Collected Papers of Charles Sanders Peirce vol. 7, 8. Hartshorne, Charles; Weiss, Paul (eds.). Cambridge: The Belknap Press of Harvard University Press.

Simmons, Rachel 2002. Odd Girl Out: The Hidden Culture of Aggression in Girls. New York: Harcourt, Inc.

Weininger, Otto 1906. Sex and Character. (Trans. from the 6th German edition.) London: William Heinemann.

Wiseman, Rosalind 2002. Queen Bees and Wannabes. London: Judy Piatkus Ltd. 


\section{Семиотика сексуальности: выбор становится привычкой, желанием, потребностью}

Прагматизм означает, что мы придаем значение тем вещам, которые для нас существенны. Самым существенным является все, что связано с нашим телом: глаза, уши, нос, руки-ноги, кожа, — вплоть до наших половых различий. Наши тела — эта средства, которые соединяют нас с миром, с пространством культуры. Половые различия позволяют бросить взгляд на то, как тело вбирает в себя опыт, создает свою “идентичность" и приобретает гендерные роли культуры. В своей ранней работе я рассматривал привычки и ассоциативное обучение (именно их Пирс считает фундаментальными свойствами познания) в контексте Dasein Хайдеггера. В настоящей работе я развиваю эти идеи с целью их применения в понимании гендерных ролей. Из неразрывной связи между привычкой, ассоциативным обучением и Dasein мы можем вывести, что 1) гендерные роли являются привычкой, 2) гендерные роли являются выбором, 3) женщинам и мужчинам нравятся те роли, на которые они определены (это фундаментальное проявление Dasein). Taким образом, выбор становится привычкой, затем желанием и наконец потребностью. Так возникают потребности, по которым идентифицируют гендерные роли.

\section{Soolisuse semiootika: Valikust saab harjumusseos, saab soov, saab vajadus}

Pragmatism on vaade, mille kohaselt me omistame tähendusi neile asjadele, mis on meile olulised. Kõige olulisemad on asjad, mis on suletud me kehasse - silmad, kõrvad, nina, käed, jalad, nahk - kuni me sooiseäradeni. Me kehad on vahendid mis ühendavad meid maailmaga kultuuriilmaga. Sooiseärad võimaldavad heita pilku, kuidas keha vastab kogemusele, isiksusele ja lõpuks kultuuri soorollidele. Oma varasemas töös uurisin harjumusi ja assotsiatiivset õppimist (neid peab Peirce tunnetuse fundamentaalseiks omadusteks), Heideggeri 'olemasolemise' kontekstis. Käesolevas töös arendan ja rakendan seda vaadet soorollidele. Lahutamatust seosest harjumuste, assotsiatiivse õppimise ja olemasolemise vahel saame tuletada, et (1) soorollid on harjumused; (2) soorollid on valitud; (3) meestele ja naistele "meeldivad" need rollid millesse nad on määratud (see on olemasolemise fundamentaalne avaldumine). Seega - valikust saab harjumuste seos, saab soov, saab vajadus. Nii tekivad vajadused, mille järgi soorolle identifitseeritakse. 